\title{
The Codification of the Polish Substantial Criminal Law in the Sejm Debates 1818
}

\author{
A Practical Test of the Precedence of the 1815 \\ Constitution of the Kingdom of Poland
}

\author{
Marcin Byczyk
}

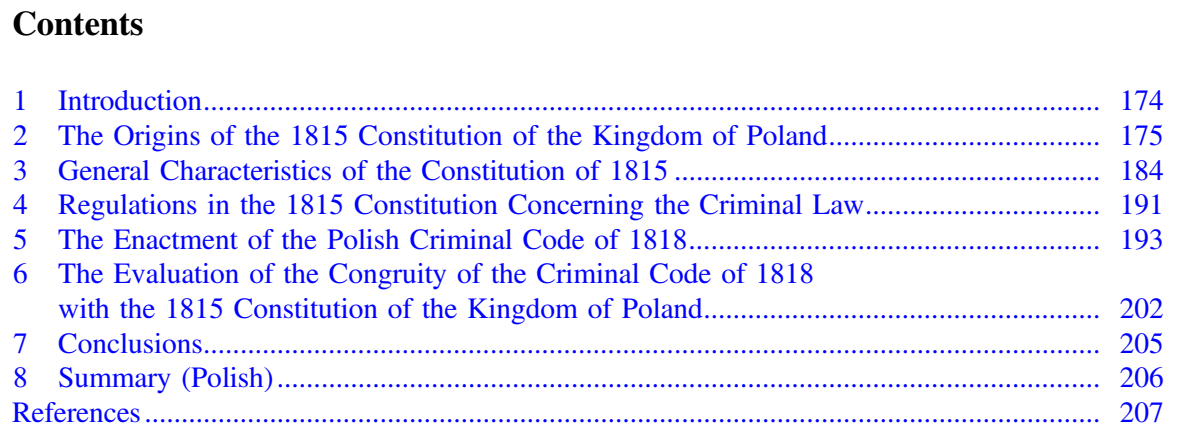

\begin{abstract}
This article is devoted to the question of the precedence of the 1815 Constitution of the Kingdom of Poland. The paper has been divided into three major parts.

In the first, introductory part the origins of the 1815 Constitution are discussed. This part of the article presents the current state of the art of the polish legal history concerning the genesis of this highest normative act of the 1815-1830 Polish Kingdom. Following the explanations provided by of S. Askenazy, H. Izdebski, D. Nawrot and S. Smolka, it has been expounded that the idea of a Constitution for a semi-independent Polish Kingdom was conceptualised as a propaganda instrument in the intellectual tug of war between France and Russia over the Polish society during the Napoleonic Wars. The Constitution itself had been being elaborated since 1811 with the participation of various polish politicians of the pro-Russian party, including F. K. Drucki-Lubecki, M. K. Ogiński, L. Plater and prince A. Czartoryski. After the ground-breaking victory of the
\end{abstract}

M. Byczyk (ه)

University of Passau, Passau, Germany

e-mail: marcinbyczyk@googlemail.com

(C) The Author(s) 2018

U. Müßig (ed.), Reconsidering Constitutional Formation II Decisive Constitutional Normativity, Studies in the History of Law and Justice 12, https://doi.org/10.1007/978-3-319-73037-0_4 
sixth coalition spearheaded by Alexander I Romanov over the French forces, it became a founding stone of the newly re-established Polish Kingdom.

In the next part of the this short study, the main regulations of the Polish 1815 Constitution have been outlined, with the special focus on those regulations which pertain to the precedence of Constitution and to the criminal law.

The third main part of the article discusses the issue of the supremacy of the 1815 Constitution with reference to its relationship with the ordinary legislation adopted in the Polish Kingdom. It has been illustrated with an analysis of legislative process of the only (apart from the Civil Code of the Kingdom of Poland 1825, which de facto was a very slight modification of the Napoleonic Civil Code) fully-fledged codification of the entire branch of law which succeeded in being adopted by the Parliament ("Sejm") of the Kingdom of Poland: the Criminal Code of 1818. Those parliamentary debates have so far not been analysed more extensively (the valuable, yet short reference made by J. Śliwowski - to whom I am very indebted for his great and inspiring study on this piece of legislation - in his monograph almost 60 years ago can hardly be considered to be exhausting in this respect) in the literature of the subject. The speeches held by the polish deputies to Sejm of the year 1818 explicitly corroborate that a rhetorical argument of a possible unconstitutionality or conversely, congruence with the 1815 Constitution, was widely invoked by both the supporters and opponents of the project. This striving for coherence of the to-be-legislated normative act with the Constitution was also reflected in the adopted legal text of the Code itself, which was to a great extent compatible with the stipulations of the 1815 Constitution. Thus, this short investigation leads to the conclusion that at this point of the development of the Polish constitutional discourse it can be stated that ground-breaking idea of the supremacy of the Constitution was already clearly recognised.

\section{Introduction}

The importance of understanding Constitutions not merely as legal texts, but also taking into account "societal context, political practice and respective constitutional interpretation" calls for detailed studies how the constitutional principles were incorporated and developed in the ordinary legislation. This approach will be applied in the following paper to investigate into the relationship between the notoriously liberal Constitution of the Polish Kingdom of 1815 and one of the very few examples of a more comprehensive legislation which succeeded in being adopted in this Russian protectorate before the beginning of its annihilation after the fall of the November Uprising in 1831-Criminal Code of $1818 .^{2}$ Therefore the paper-in line with the main principles of the ReConFort research

\footnotetext{
${ }^{1}$ Müßig (2014, 27, p. 122).

${ }^{2}$ It would be very difficult to call the Polish Civil Code of 1825 (Kodex Cywilny Królestwa Polskiego z 1825 r.) as an independent codification since it as A. Dziadzio rightly states (cf. Dziadzio 2008, p. 229) it: "in fact was a slight novelization of those regulations of Napoleon's Code which did not find social approval".
} 
program $^{3}$ focuses not on "an abstract perception of the political history of ideas" but on "the political polemics in concrete situations of conflict". 4

\section{The Origins of the 1815 Constitution of the Kingdom of Poland}

The Constitution of the Kingdom of Poland belongs to the rather less researched into among all of the European Constitutions of the XIX century; especially any kind of more extensive literature in the English language is missing. For this reason it appears crucial to make a brief introductory presentation of this legal act, aimed not only at characterising its textual content, ${ }^{5}$ but much more importantly, at expounding the intricacies of its creation and implementation in the Kingdom of Poland.

In the following part I will be relaying on the findings of the polish secondary literature of the subject, especially on the fundamental works of S. Askenazy, ${ }^{6}$ H. Izdebski, ${ }^{7}$ Dariusz Nawrot ${ }^{8}$ and S. Smolka ${ }^{9}$ whose contributions provided us with almost everything that we currently know about the genesis of this highest normative act of the Polish Kingdom 1815-1830. Therefore, this part of the article, itself not adding to the state of the art but rather and mostly narrating the already established conclusions in the polish legal history, will serve as an introduction ${ }^{10}$ to the presentation of the debate on the Sejm in 1818 in the subsequent part of this paper.

At the very beginning of this sketch it has to be stressed that due to the incompleteness of the preserved sources from the period of creation of the 1815 Constitution it is impossible to state with certainty what were the origins of this

\footnotetext{
${ }^{3}$ As it has been stressed by principal investigator of the ReConFort ERC Advanced Grant, Müßig (s.a., p. 3) the research within this scientific enterprise is directed not merely at analysing the legal texts of the past Constitutions, but includes a much broader perspective where "the constitution is understood as an evolutionary achievement of the interplay of the constitutional text with its contemporary societal context".

${ }^{4}$ Müßig (s.a., p. 6).

${ }^{5}$ Which to the necessary extent will be discussed later in this article. All the quotations of the regulations of the Constitution of Poland 1815 will be made according to the English translation of this legal act published as: Constitutional charter of the Kingdom of Poland in the year 1815, London 1831.

${ }^{6}$ Askenazy (1907). The contribution of Szymon Askenazy is particularly valuable since this author did have access to the sources which subsequently, during the upheaval of the war were lost and subsequent authors have to rely on him, cf. e.g. Izdebski (1990, pp. 194).

${ }^{7}$ Izdebski (1972). This explanation of the genesis of the polish Constitution has also been repeated by Izdebski (1990, pp. 185-198).

${ }^{8}$ Nawrot (2008).

${ }^{9}$ Smolka (1907).

${ }^{10} \mathrm{I}$ considered such a prolonged introduction especially necessary for the international reader who may not be able to access the relevant literature in the polish language and bearing in mind that the facts concerning the origins of the Polish 1815 Constitution are little known outside Poland.
} 
normative act. ${ }^{11}$ Nonetheless there can be no doubts that after the fall of the Polish Commonwealth in the year 1795 the Polish and Lithuanian nobility living in the regions incorporated into the tsar's Empire adopted a somewhat ambiguous approach towards the Russian authorities. ${ }^{12}$ Praising them for providing stability and security ${ }^{13}$ was simultaneously intertwined with conceptualising plans and requests to obtain more autonomy under the Russian protectorate ${ }^{14}$ and subsequently (approximately since May 1810) with attempts to decrease taxation burdens imposed by the Russian authorities. ${ }^{15}$ Such a situation is to be explained by the fact that the great Polish noblemen ("magnateria"), after the fall of the Polish Commonwealth did not obtain independence or more autonomy, but, due to their weakness-were rather forced to seek accommodation with the partitioning powers. ${ }^{16}$ Moreover, there was a profound conviction that the fate of Polish

\footnotetext{
${ }^{11}$ The most comprehensive explanation, which is also shared by the author of this article, has been provided by H. Izdebski, who (similarly as S. Smolka already did in the year 1907) pinpointed to the fact that the first drafts of this Constitution go back to the period of the years 1811-1812, when Alexander I attempted to create a counterbalance for the Duchy of Warsaw by reviving the Grand Duchy of Lithuania and equipping it with a semi-independent position, founded on a granted Constitution. Cf. Izdebski (1972, p. 109). This explanation of the genesis of the polish Constitution has also been repeated by Izdebski (1990, pp. 185-198). Those findings of H. Izdebski, being in the authors' opinion the most convincing and also coherent with the views of the earlier researchers, at many places have been inspiration for the narration ensuing here. I am also very indebted to Izdebski for his lavish footnotes, which proved to be very valuable when beginning to seek for the relevant sources for the ReConFort project.

${ }^{12}$ It is also worth mentioning that this refers also to the attitude of Polish nobility towards two others countries which took part in the partition of the Polish territories, cf. in this respect general remarks of Lelewel (1961, p. 476).

${ }^{13}$ Szoper (2004, p. 244) and Izdebski (1972, pp. 96-97). This last author, noting this accommodating positions of the polish nobility quotes here Kajetan Koźmian, a prominent polish nobleman, who in his memoirs $(1858$, p. 296) supposedly wrote: "In some respect we have it better than during the polish times, we have a bigger part of that, what our home country gave us, but we do not have burden and danger of a massacre of Uman [the massacre of ca. 2000 Polish and Jewish inhabitants of the town Uman during the Ukrainian haidamack rebellion in 1768 - information by the author], and be it without Poland, we are in Poland and we are Polish". Yet it has to be stressed that the copy of those memoirs available to the author does not contain such a statement on the mentioned page. Furthermore, as it has been established in the detailed research into the economic situation in Lithuania, it did deteriorate sharply after the year 1805, with the loss of more than $20 \%$ of population and significant increase in taxes levied by the Russian authorities (for the meticulous overview of the economic situation of the Grand Duchy after the fall of Polish-Lithuania cf. Nawrot (2008, 65-69) and the literature quoted there). Therefore the view of Szoper (2004, p. 244), who speaks about merely "negligible fiscal burdens collected for Imperial treasury" appears to be wrong.

${ }^{14}$ Such attempts were already undertaken in 1805 by Prince Adam Czartoryski [cf. in this respect Skowronek (1969, pp. 201-236)] and were aimed at re-establishing semi-autonomous Poland under the Russian protectorate.

${ }^{15}$ Nawrot (2008, pp. 68-69).

${ }^{16}$ Kowalski (2013). Therefore, as the cited author rightly points out (p. 256), their political situation was entirely different from that of the position of the German princes, who following the fall of Sacrum Imperium Romanum frequently obtained territorial sovereignty.
} 
Commonwealth ended definitely. ${ }^{17}$ As it has been established so far in relevant the literature of the subject, ${ }^{18}$ those attempts for more autonomy for former polish territories remained grossly futile and did not amount to demands for granting a separate constitution.

The situation changed dramatically after the Napoleon's war with the fifth coalition in the year 1809, which brought a stunning victory of the Duchy of Warsaw over the Austrian Empire and enabled it to expand its borders as to incorporate some of the recently partitioned Polish territories. ${ }^{19}$ It simultaneously instilled apprehension in the Russian authorities of an imminent danger of reviving an independent and potent Polish state, ${ }^{20}$ what would annihilate the endeavours of the Russian foreign policy of at least the last 50 years and could provoke unrest in the remaining, incorporated territories belonging previously to Polish-Lithuanian Commonwealth. ${ }^{21}$

Consequently, tsar Alexander I Romanov, following a memorandum elaborated by M. Speranski on 11 March $1811^{22}$ commenced to canvass for support among the Polish-Lithuanian nobility by beguiling it with a perspective of more autonomy as well as political and economic liberties. For this reason during the stay of M. K. Ogiński in Petersburg starting in April 1811, this Polish mighty nobleman ("magnat"), since 1810 also a Russian senator, was invited by the Russian tsar to present him propositions apt for satisfying the political expectations and demands of the polish population (what of course was meant here was practically solely the nobility) in the western provinces ("gubernii") of the Russian Empire. ${ }^{23}$ Answering

\footnotetext{
${ }^{17}$ Adam Czartoryski wrote about those times: "After the joys of $3 \mathrm{rd}$ May, deep sorrow, black and paralysing distress took over Poland", cf. Czartoryski (1860, p. 117).

${ }^{18}$ For the general presentation of those attempts cf. Izdebski (1972, pp. 96-97) and the literature quoted there.

${ }^{19}$ Including several major cities such as Cracow or Lviv. Cf. in this respect Czubaty (2011, pp. 198-234) or Thaden (1984, p. 64 et seq.)

${ }^{20}$ Very significant is a remark made by M. Speranski that Poland is " a week point in all our political considerations", cf. N. F. Dubrovin, Zapiska MM Speranskogo o veroatnostah wojny s Franciej, Russkaa starina 1900, vol. 101, pp. 58-65, quoted after Nawrot (2008, p. 63).

${ }^{21}$ Nawrot (2008, p. 64).

${ }^{22}$ Russkaa starina 1902, vol. 108, pp. 257, quoted after Nawrot (2008, pp. 64-65).

${ }^{23}$ According to the memoirs of Ogiński (1872, vol. III, p. 19) from the meeting with tsar in May 1811: "What concerns the current moment, said the tsar, I should limit myself to a wish that polish citizens living under my rule were happy and content, and if you can purvey to me certain projects in this respect I will occupy myself with them with pleasure". Very informative appear the comments written down by M. K. Ogiński during the subsequent meeting with Alexander I in November 1811 (according to the Gregorian calendar), where supposedly the tsar said: "One of the two should ensue: in case of war I will create a Polish Kingdom, which will be united with the Russian Empire like Hungary and Czech with Austria or when there will be no war, I will introduce our great plan in respect to Lithuania", cf. Ogiński (1872, vol. III, p. 43). For a more profound discussion of this political game of the Russian authorities cf. Nawrot (2008, pp. 69-83), Izdebski (1972, pp. 96-99) and Wilham L. Backwell, Alexander I and Poland. The foundations of his Polish Policy and its repercussions on Russia, 1801-1825, unpublished Ph.D. thesis, Princeton 1959, a possibly interesting dissertation I was made attentive to by Thaden $(1984$, p. 64, Footnote 1$)$.
} 
this invitation, during one of the following meetings of M. K. Ogiński (which has the date of 22 October 1811 in the memoirs ${ }^{24}$ ) with Alexander I, the polish nobleman attached to a letter to the tsar a project of ukaz on creation of Duchy of Lithuania, ${ }^{25}$ highlighting the need for guarantying due respect for the old polish law, polish language and the monopoly of the public offices for "citizens living and having property in the Grand Duchy". ${ }^{26}$ This ukaz was so much more far-reaching than earlier similar propositions that in the contemporary secondary literature it has been labelled as "project of the Constitution of Grand Duchy of Lithuania". 27

It appears to be relevant in this context to stress that M. K. Ogiński in this very correspondence with Alexander I mentioned "certain explications which [he has] gathered in respect to the administration of Finland". ${ }^{28}$ This very fact hints at a possibility that he already had entered in closer relationships with the Russian and pro-Russian agents occupying themselves with the issue of the newly conquered Finland, which is the more probable, as the members of the so-called Committee for the Finnish issues were meeting in Sankt Petersburg since $1811 .^{29}$

Approximately at the same time, possibly starting from December 1811, a first project of what was proposed to become the highest normative act of the reborn, autonomous Lithuania was elaborated, and its authorship is tentatively attributed to two important finish politician of the pro-Russian orientation: G. A. Rosenkampff

\footnotetext{
${ }^{24}$ Ogiński (1872, vol. III, pp. 46-48).

${ }^{25}$ As Ogiński (1872, vol. III, p. 46) stated, he considered that it was "the fastest and easiest way to manifest from which stance I see the organisation of Lithuania" It is interesting to note that according to S. Smolka M. K. Ogiński was not an author of this text himself, but rather F. K. Drucki-Lubecki and Kazimierz Plater, who was to have been inspired to work upon the question of autonomy of the Grand Duchy of Lithuania by M. Speranski, cf. Smolka (1907, vol. II, pp. 495-498).

${ }^{26}$ Ogiński (1872, vol. III, pp. 46-48). This project amounted to 11 articles.

${ }^{27}$ Izdebski (1972, p. 97); identical statment is made by Nawrot (2008, p. 73), who speaks about „striving to grant to the Grand Duchy of Lithuania a charakter of a state and national”. This opinion seems to be exaggerated since the project in its Art. VI clearly stated that the organisation of the Duchy is to be developed by a "general law" which was to be elaborated by a special committee. This ukaz could hardly be anything else than a prologue for future constitutional works. It is to be noted that H. Izdebski mentions that some of the prominent polish noblemen of the pro-Russian orientation in Lithuania, namely L. Plater and F. K. Drucki-Lubecki claimed to be involved in the preparation of the project of this proclamation, referring himself in this respect the correspondence between L. Plater and A. Czartoryski from November 1811-Izdebski (1972, p. 99), footnote numbers 20-22. In the correspondence between L. Plater and A. Czartoryski recovered by the author of his text and scanned for the purposes of the ReConFort projectnamely in The Princes Czartoryski Library's source number: 5511 V, 81-92, which appears to be closest to the source meant by H. Izdebski, there are indeed some confirmations of this thesis, especially the mentions of "Drucki de Lithuanie", cf. The Princes Czartoryski Library source number: $5511 \mathrm{~V}$, p. 82).

${ }^{28}$ Ogiński (1872, vol. III, p. 44).

${ }^{29}$ It was established in 1811 by Gustav Mauritz Armfelt, cf. Thaden (1984, p. 201).
} 
and G. M. Armfelt. ${ }^{30}$ It is also surmised that then responsible for both polish and finish issues, the mighty close advisor of tsar Alexander I, M. Speranski was personally involved in shaping some of the stipulations of this draft. ${ }^{31}$ This document appears to have been lost irretrievably, ${ }^{32}$ yet it in the part of the Polish historic studies it is claimed that the preserved draft entitled Projet de Constitution du Royaume de Pologne (highly probably, if not certainly elaborated in the year 1812 ) is nothing else than its (slightly?) amended version. ${ }^{33}$

The further important step in the genesis of the Polish 1815 Constitution was the presentation of the project called "The governmental law of the Grand Duchy of Lithuania" ("Ustawa rzadowa Wielkiego Księstwa Litewskiego"). ${ }^{34}$ This document, which had 266 articles and was developed $^{35}$ jointly by Prince F. K. Drucki-Lubecki and M. K. Ogiński, who is thought to have corrected the first draft elaborated by L. Plater, ${ }^{36}$ was presented to tsar Alexander I after he expressed his disappointment

\footnotetext{
${ }^{30}$ Izdebski (1972, pp. 105, 114-117), who refers to the memoirs of Ogiński (1872, t. III, p. 52), where the latter states that in December 1811 he found out "that the tsar ordered general Armfelt and baron Rosenkampff to elaborate a law for the inhabitants of Lithuania". Here especially the figure of Gustaf Mauritz Armfelt appears to be of key importance and merits a closer characteristic. Gustaf Mauritz Armfelt born in 1757 was one of the most prominent politician of the pro-Gustavian orientation at the end of XVIII century/beginning of XIX century. He distinguished himself in the service for King Gustav III, for whom he served between 1780 and 1792. After the death of Gustav, he plotted with Catherine II for a military intervention in Sweden in favour of the Gustavian-party. Barely surviving an attempt at his life in Naples, he fled to Russia where he stayed until 1797. Rehabilitated by Gustav IV of Sweden, he once again entered the King's service until the latter was deposed of the crown by the revolution of 1809. After the revolution Armfelt embarked once again on service for Russian Empire and became one of the closest advisors of Alexander I, canvassing for a plan of autonomous Finland, whose General Governor he became in the year 1813. For more information about Gustaf Mauritz Armfelt cf. Stig Ramel, Gustaf Mauritz Armfelt, fondateur de la Finlande, Paris 1999.

${ }^{31}$ Such a thesis was proposed by Izdebski (1972, p. 113), who founds it on attempts of the project to preserve to the highest possible extend local customs and laws, an approach supposedly typical for the policies of M. Speranski. An opposing view, attributing this draft to Michat Kleofas Ogiński was put forward by Iwaszkiewicz (1912, pp. 44-47), who based it on the fact that the project had "strong mark of the oligarchical tendencies of the Lithuanian magnetaria" (cf. p. 46); it has been also discussed extensively by Izdebski (1972, p. 116).

${ }^{32}$ This claim could be finally falsified after the queries Russian archives were made, but this so far has not been accomplished.

${ }^{33}$ Izdebski (1972, pp. 117-119). Such a view had already been expressed by Smolka (1907, vol. II, p. 505), who wrote: "Maybe this second preserved [project] in the papers by Lubecki was a polish modification of the creation of Armfelt and Rosenkampf. Yet we do not have any explicit indications in this respect", yet the authors disagree on who was responsible for those modifications. Its (possibly only) copy is available in the Drucki-Lubecki collection within the The Princes Czartoryski Library in Cracow, source number 13078 A5 and has been retrieved by the author and enclosed to this book as Appendix C, translated by the PI Ulrike Müßig.

${ }^{34}$ Cf. Smolka (1907, vol. II, pp. 128-129).

${ }^{35}$ Smolka (1907, vol. II, pp. 131, 497-498 and 505-508), cf. also Izdebski (1972, p. 99). This source is available in the The Princes Czartoryski Library in Cracow, source number 13078 A5 and has been made available in the Internet database of the project under: http://sources.reconfort.eu/.

${ }^{36}$ Nawrot $(2008$, p. 74$)$ and the literature quoted there.
} 
with another, earlier project, probably that elaborated by G. A. Rosenkampff and G. M. Armfelt. ${ }^{37}$ The meticulous comparison of its content with the subsequent Constitution of the Kingdom of Poland of 1815 reveals some semblances between the two documents, especially in the structuring of its main editorial subdivisions. ${ }^{38}$

The both aforementioned drafts were sent-with a letter from 13th April $1812^{39}$ - to Prince Adam Czartoryski, the most prominent polish politician of the pro-Russian orientation of the time for counselling, who advised elaborating another, compromising project. ${ }^{40}$ Yet, before this could become reality, the war with Napoleon broke out.

Following the spectacular victory over the Grand Army in the year 1812 and during the ensuing military occupation of the Duchy of Warsaw by the Russian military forces, ${ }^{41}$ the idea of creating dependent states with formally stipulated autonomy, founded on a Constitution, became politically viable. ${ }^{42}$ It finally led to

\footnotetext{
${ }^{37}$ Ogiński (1872), Oddział III, p. 74 wrote in his memoirs that during his meeting with Alexander I on 27th of January 1812 (8th February according to the Georgian calendar) the tsar stated that: "he does not like the project that was submitted to him and that he intends to order me creating a different one" and upon this statement the Ogiński asserted that: "he occupied himself for months with this work with the prince Lubecki and duke Kazimierz. Plater, that they divided all the materials for this work between themselves and that they have been laid down in such a way that can it be anytime presented to the tsar", cf. Ogiński (1872), Oddział III, p. 74. However it is only a presumption, yet be the more probable as it necessarily must have flattered the Polish-Lithuanian nobility and can be perceived as nothing but a skilful political gesture by the Russian tsar. It also may hint at a fact that the works upon the project of the Governmental Law... might have had begun earlier.

${ }^{38}$ Such a detailed comparision has already been conducted: cf. Izdebski (1972, p. 125). Cf. also considerations below (Fn 60).

${ }^{39}$ Smolka (1907, pp. 162-165).

${ }^{40} \mathrm{Cf}$. letter of Adam Czartoryski to tsar Alexander I from 04.06.1812 and an addition to it from 13.6.1812, quoted extensively and discussed by Smolka (1907, pp. 165-168). Some of this relevant correspondence between Prince Adam Czartoryski and tsar Alexander I. was reprinted in: Czartoryski (1888, pp. 213-237), which has been scanned within the ReConFort project and has been made available in the Internet database of the project under: http://sources.reconfort.eu/. For those proceedings cf. Izdebski (1972, p. 118) and Nawrot (2008, p. 82).

${ }^{41}$ Beginning in February 1813.

${ }^{42}$ Izdebski (1972, p. 121). It is also interesting to note that prince Adam Czartorski in his correspondence with Alexander I Romanov (cf. letter of Adam Czartoryski to tsar Alexander I from 04.05.1813, reprinted in: Czartoryski (1888, pp. 237-238) wrote: "The King of Prussia is not at all opposed to the existence of Poland. He feels the necessity of satisfying the wishes of the Polish nation and considers them just and reasonable". On the other hand tough Prince Adam Czartoryski urged: "The tsar Alexander wants the Poles to make a step towards him, he needs evidences of theirs' sympathy which he could place in front of the allied and the Russian" (cf. Adam Jerzy Czartoryski, Memoriał w sprawie odbudowy państwa polskiego, source retrieved by the author and made available on the internet platform of the project under: http://sources. reconfort.eu/, The Princes Czartoryski Library, source number: 5242 V, 96). At the same time however there can be encountered voices demanding a closer alliance with Austria (cf. s.n., Co nam dziś czynić przystaje, source retrieved by the author and made available on the internet platform of the project, The Princes Czartoryski Library, source number: 5242 V, 67-80, especially pp. 76-77).
} 
granting Constitution to the Kingdom of Poland in November 1815 by the Russian tsar. ${ }^{43}$ This stage had been preceded by the elaboration of the Principles of the Constitution Kingdom of Poland ("Zasady Konstytucji Królestwa Polskiego z dn. 25 maja 1815 r."), ${ }^{44}$ proclaimed by Alexander I a few weeks after the ratification of treaties of Vienna 1815 , i.e. on 25 May $1815 .^{45}$

The principles themselves already laid down two most significant rules which found their expression in the future text of the Constitution 1815: the eternal union with the Russian Empire ${ }^{46}$ and the monarchical principle, i.e. the assumption that the entire power stems from the person of the ruler. ${ }^{47}$ They also stipulated numerous liberties, which were to be subsequently incorporated into the text of the future Constitution, such as habeas corpus, ${ }^{48}$ freedom of the press, ${ }^{49}$ protection of property ${ }^{50}$ or religious freedom. ${ }^{51}$ Yet the principles could not substitute a veritable constitution and had only temporary significance. ${ }^{52}$

\footnotetext{
${ }^{43}$ It had the signing date of 27 th November 1815 but formally entered into force on 24 th of December 1815.

${ }^{44}$ Cf. Zasady konstytucji Królestwa Polskiego (Principles of Constitution of the Polish Kingdom), printed Polish source available in Handelsman (1915, pp. 34-40). This document, consisting of 37 articles - was in fact a stub of a future constitutional regulation. Its roots go at least to a meeting which took place on 21st of September 1814 in Puławy (residence of Prince Adam Czartoryski) where the draft of those principles had been discussed with the participation of i.a. tsar Alexander I, Adam Czartoryski, Nikolay Novossiltzoff and Tadeusz Matuszewicz. For the copy of protocol from this meeting in French, written by A. Skałkowski cf. Askenazy (1937, pp. 369-373), cf. also: Mycielski (2010, p. 55).

${ }^{45}$ It is worth stressing that art. 3 of the Vienna treaty between Russia and Prussia as well as art. 5 of the Vienna treaty between Russia and Austria guaranteed creating a Kingdom of Poland which shall be connected with Russian Empire by the means of its Constitution. Both those treaties are available in English i.e. in Journals of the House of Commons, vol. 71, s.1., 1816, pp. 747-750. ${ }^{46}$ Art. 1 of the Principles of the Constitution of Kingdom of Poland.

${ }^{47} \mathrm{Cf}$. art. 3 of the Principles of the Constitution of Kingdom of Poland, which stated that "the executive competence and the government are fully placed in the person of a ruler; all the executing and administrative power can only stem from him".

${ }^{48}$ Cf. art. 4 of the Principles of the Constitution Kingdom of Poland and art. 19 of the Polish 1815 Constitution.

${ }^{49} \mathrm{Cf}$. art. 10 of the Principles of the Constitution Kingdom of Poland and art. 16 of the Polish 1815 Constitution.

${ }^{50}$ Cf. art. 6 of the Principles of the Constitution Kingdom of Poland and art. 26 of the Polish 1815 Constitution.

${ }^{51}$ Cf. art. 2 of the Principles of the Constitution Kingdom of Poland and art. 11 of the Polish 1815 Constitution.

${ }^{52}$ It was already recognised by the contemporaries: in the source retrieved by the author and made available on the internet platform of the project under: http://sources.reconfort.eu/, i.e. Ludwik Plater, Myśli wzgledem Rozwiniecia Zasad Konstytucyynych, The Princes Czartoryski Library, source number: 5261 IV, 295-299 (295) this author, working upon the Constitutional drafts stated: "It is impossible though to commence working on the details without having principles, which make out the generality. Such principles are partially the Constitutional Principles".
} 
The widespread view in the Polish legal history ${ }^{53}$ states that the fervent half-year period $^{54}$ between the acceptance of the Principles of the Constitution of the Kingdom of Poland from 25th May 1815 and its final signing on 27th November 1815 abounded in constitutional drafts. ${ }^{55}$ The need for such drafting was further exacerbated by the fact that part of the polish society ${ }^{56}$ was against restoring the Constitution of 3rd May 1791, a postulate which had been formulated by the conservative circles of the Duchy of Warsaw $^{57}$ and which even had been alluded to in Art. 1 of the Principles of the Constitution of the Kingdom of Poland from 25th May $1815 .^{58}$

The most significant of those projects is a 438-articles long document, attributed solely to L. Plater and submitted to the provisional government of the Kingdom in a letter dated on 26 August $1815 .^{59}$ It is highly probable that due to the similarities between Plater's project and "The governmental law of the Grand Duchy of

\footnotetext{
${ }^{53}$ Askenazy (1907, pp. 66-72), Bartoszewicz (1916, pp. 213-216) and Izdebski (1990, pp. 193198). This has been confirmed in the light of the sources retrieved by the author for the database of the ReConFort project.

${ }^{54}$ According to the source retrieved by the author and made available in the Internet database of the project under: http://sources.reconfort.eu/: Kajetan Koźmian (?), Notatki o pracach nad konstytucją Królestwa Polskiego, The Princes Czartoryski Library, source number: 5242 V, 343-344, (344): "Only after returning back from the Congress did we start to think seriously about the text of the Constitution".

${ }^{55}$ There were at least three such projects: of A. Horodyski, The Princes Czartoryski Library, source number: 5261 V, 219-292, cf. in this respect Kallas (1969, pp. 105-116), an anonymous project supposedly available in Muzem Narodowe w Krakowie, source number according to H. Izdebski: $1025 / 22$, which was based on the idea of joining the former Duchy of Warsaw with the territories of former Duchy of Lithuania, cf. for the discussion of those ideas and promises starting from 1815 Mościcki (1924, pp. 84-96) and the project of L. Plater, The Princes Czartoryski Library, source number: $5261 \mathrm{IV}, 3-110$. The first and the last of the aforementioned projects have already been retrieved for the purposes of the project, scanned and has been made available in the Internet database of the project under: http://sources.reconfort.eu/.

${ }^{56}$ Cf. especially a source quoted extensively by Mycielski (2010, p. 53), namely: Józef Kalasanty Szaniawski, Ogólniejsze myśli względem projektowanej konstytucji Królestwa Polskiego, manuscript, which according to M. Mycielski is to be available in Zielińskich Library in Płock under the source number 511. Cf. also Stanisław Wegrzycki, Przestrogi do utworzenia Królestwa Polskiego, 1813; The Princes Czartoryski Library, sources number: 5242 V, 125 who in the year 1813 in this source retrieved by the author and made available in the Internet database of the project under: http://sources.reconfort.eu/. stated: "It is necessary to give a Constitution, but not to go back to the Constitution of 3rd May 1791 since this one was at that time good, but nowadays the Constitution granted to the Duchy [of Warsaw-M. Byczyk] following the Tylzycki treaty in the year 1807 is better for all".

${ }^{57} \mathrm{Cf}$. in this respect e.g. Józef Wielhorski, Reflexions sur le Royaume de Pologne en 1815 , reprinted in: Szymon Askenazy, Ministerium Wielhorskiego in: idem, Dwa stulecia. XVIII i XIX. Badania i przyczynki, vol. II, Warszawa 1910, pp. 519-522, who discussing such views wrote (p. 520): "La constitution de 1791 prouve un progres incroyablemais il est imposible de ne pas s'apercevoi que' l'on a regarde la Pologone comme un malade".

${ }^{58}$ Where it had been stated that "new Constitution, which was to be granted to the Kingdom of Poland, could be even more national and became close to the law of 3rd May 1791 to the extent to which the difference in circumstances and times enables it".

${ }^{59} \mathrm{Cf}$. Izdebski (1972, pp. 123-124).
} 
Lithuania" ("Ustawa rzadowa Wielkiego Księstwa Litewskiego") this last paper must have had been an important source of inspiration for L. Plater. ${ }^{60}$ Due to the supposed criticism issued at this draft by numerous prominent figures of the then polish public life, including A. Czartoryski, A. Linecki ${ }^{61}$ as well as by I. Sobolewski ${ }^{62}$ and J.K. Szaniawski ${ }^{63}$ it was profoundly reshaped and shortened, possibly by a wider commission of the polish politicians of the time, probably including F. K. Drucki-Lubecki, T. Wawrzecki and A. Czartoryski, ${ }^{64}$ flavouring it with a distinctively liberal spirit. According to S. Akenazy it resulted in creating a new, concise project of 162 articles which was then submitted to the monarch during his stance in Warsaw in November 1815, who after annotating it, referred it to Ignacy Sobolewski for further revision. ${ }^{65}$ The final touch nonetheless belonged to the hand of the absolute tsar Alexander I, who once again comprehensively reviewed the draft before ratifying it. ${ }^{66}$

\footnotetext{
${ }^{60}$ Those similarities concerned numerous issues such like the relationship between the Kingdom of Poland and the Russian Empire, the organisation of the territorial administration, the Senate, or the procedures of amending the Constitution. For the detailed analysis of the similarities and divergences cf. Izdebski (1972, pp. 125-131).

${ }^{61}$ The claim about such a criticism have been formulated by Izdebski (1972, p. 126) who referred himself to a letter of A. Linowski to Adam Czartoryski from 10th April 1812 (The Princes Czartoryski Library, source number: 5259 IV , 167) and to a letter of A. Linowski to A. Czartoryski from 25th March 1812 (The Princes Czartoryski Library, source number: 5259 IV, 163). Yet an attempt to recover those letters made by the author of this article proved that they are not available under the mentioned location. It has to be stressed however that also Askenazy (1907, p. 67) referred to: "critical remarks made on this project by Czartoryski, Szaniawski, and particularly by the enlighted Ignacy Sobolewski".

${ }^{62}$ Ignacy Sobolewski in his memorandum, recovered by the author and inserted into the database of the project, criticised the draft i.a. for being all too similar to the regulations of Constitution of 3rd May, e.g. by introducing in its regulations (in the title $\mathrm{X}$ ) upon the periodical revival of Constitution every 25 years, whereas Sobolewski deemed it sufficient to require here a qualified majority of $4 / 5$ of the representatives to Sejm and Senate, cf. source retrieved by the author and made available in the Internet database of the project under: http://sources.reconfort.eu/: Ignacy, Sobolewski, Uwagi na projektem ustawy konstytucyjnej z 438 artykułów złożonym, The Princes Czartoryski Library, source number: 5222 V, 163-184, especially pp. 182-183.

${ }^{63}$ Józef Kalasanty Szaniawski in his written opinion, recovered by the author, criticised the draft i. a. for introducing regulations that were in his view superfluous, such as regulations upon the viceroy or the States' Council, since: "The State's Council is a thing entirely dependent from the monarch and the Constitution does not have much to say here", cf. source retrieved by the author and made available on the internet platform of the project under: http://sources.reconfort.eu/: Józef Kalasanty Szaniawski, Uwagi nad projektem ustawy konstytucyjnej, The Princes Czartoryski Library, source number 5222 V, 389-411, (397-398).

${ }^{64}$ Izdebski (1972, p. 131), who also mentions the following persons: A. Linowski, F. Grabowski, S.K. Zamoyski, T. Matuszewicz as possible participants of such a committee. Bartoszewicz (1916, p. 213) also mentions N. Novossiltzoff, who was supposed to participate in the works of that Commission "at the end".

${ }^{65}$ Such is the outline of the last stages of drafting 1815 Constitution made by Askenazy (1907, pp. 67-68). It is a narration very difficult to falsify since this author did have access to the sources which are considered to be lost and have also not been found by the author of this text.

${ }^{66}$ Unfortunately and as already mentioned above, any more detailed information about the proceedings on the Constitution has been lost. The only preserved secondary source which gives an
} 
As soon as this work has been accomplished, any plans aimed at unifying Lithuania with the Kingdom of Poland were postponed indefinitely. ${ }^{67}$ This, together with the fact of instrumental treatment of drafts of the Constitution for the Grand Duchy of Lithuania, which appear to have been merely an instrument for winning over the support of Polish nobility ${ }^{68}$ and possibly providing military support for the incoming war with Napoleon reveal a true meaning of Russian policy. ${ }^{69}$

\section{General Characteristics of the Constitution of 1815}

It is not an objective of this paper to offer a meticulous overview of the regulations of the Constitution of 1815, yet owing to the shortage of the relevant English literature of the subject before more specific regulations of this normative act concerning the criminal law will be presented in depth, it appears reasonable to outline its main framework and regulatory content in general.

The Constitution of the Kingdom of Poland from the year 1815 is considerably longer then the two previous Polish Constitutions, namely the ground-braking

overview of those works is contained within the publication of Askenazy (1907, pp. 66-68), whom I followed in this part of the article. Szymon Askenazy had had access to the original documents and drafts that subsequently appear to have been lost and were also not recovered by the author of this text. The conclusions of this author are also referred to in the contemporary literature of the subject, cf. e.g. Izdebski (1990, pp. 193-198). It is worth pointing out here that as it has been observed in the literature of the subject (cf. Kozłowski 1907, p. 127) the Polish 1815 Constitution did influence the draft of the Greek Constitution of 1827.

${ }^{67}$ Very interesting is a source quoted by Szoper (2004, p. 245), namely: Ostrowski, Żywot Tomasza Ostrowskiego, Ministra Rzeczypospolitej; później Prezesa Senatu Księstwa Warszawskiego i Królestwa Polskiego oraz Rys Wypadków Krajowych od 1763 r. do 1817, vol. II, Paryż 1840, p. 632, according to which during a meeting of the representatives of the Polish-Lithuanian nobility with the tsar Alexander I Romanov on 25th November 1815 in Warsaw, the tsar supposedly stated: "I will not allow that you demanded to join your provinces to Poland, then it does not fit that it would be understood that I do it following your request", cf. also Mościcki (1924, pp. 84-96).

${ }^{68}$ However, Alexander I Romanov was careful enough to sustain the mistake of the Polish nobility: According to the Sobolewski brothers, during an audience in the year 1816: "The tsar seems to be more and more attached to our national existence as to his creation. He mentioned me with pleasure our Constitution, for which he has received i.a. congratulations from Ms. Staël", Cf. source retrieved by the author and made available on the internet platform of the project under: http://sources.reconfort.eu/: Correspondence between A. Czartoryski and Jozef, Ignacy and Ludwik Sobolewski, letter from 19.04.1816, The Princes Czartoryski Library, source number: $5515,9-15,(11)$.

${ }^{69}$ It is interesting to refer to the J. Iwaszkiewicz, who describes the attempts of tsar Alexander I Romanov to encourage M. K. Ogiński to contact Armfelt in order to find out the best ways of organizing military forces "as soon as possible", cf. Iwaszkiewicz (1912). Therefore the author can hardly agree with the view that "Alexander treated them [drafts of the Constitution of Grand Duchy of Lithuania] all the time seriously", cf. Izdebski (1972, p. 119). Rather, it was part and parcel of the instrumental Russian policy, aimed at securing its interests in central Europe. 
Constitution of 3 May 1791 and the Constitution of the Duchy of Warsaw 1807: it comprises 4453 words $^{70}$ and is divided into 7 main editorial parts - titles. ${ }^{71}$ Two most extensive titles, namely third-“Government" and forth-“Of the national representation" are additionally subdivided into respectively 5 and 6 chapters. $^{72}$ Quantitatively speaking, the most significant number of the legal norms has been devoted to the regulation of the division of powers, ${ }^{73}$ with the structure of titles number 3-5 apparently referring to the idea of trias politica whose elaboration is commonly attributed to Baron de Montesquieu.

Among those regulations upon the diverse branches of government two legal norms appear to possess towering importance for recreating the balance of power in the Kingdom, namely Art. 35, stating that: "The government resides in the person of the King. He exercises in all their plenitude the functions of executive power. All executive and administrative authority must emanate from him", supplemented by the provision of Art. 86: "The legislative power resides in the person of the King and in the two chambers of the Sejm, conformably with the regulations of the article thirty-one". Highlighting the position of the king here is not purely coincidental. It possibly stems from the final stage of the drafting of the Constitution, personally conducted by Alexander I which was aimed at securing the unalloyed supremacy of the Russian tsar in the Polish Kingdom. ${ }^{74}$ According to the 1815 Constitution such a central position of the king did not curb the freedom of the judiciary: in art. 138 there is a solemn proclamation that: "The judicial order is constitutionally independent", what is supplemented by the guarantee that "the judges nominated by the King are for life and cannot be removed". 75 There are also provisions for the highest tribunal in Warsaw, which "shall finally determine all civil and criminal cases, state crimes excepted", 76 leaving the king no other competence than to grant pardon to the offenders. ${ }^{77}$

For the purpose of a general presentation of the system of legislative and executive powers as moulded in the Constitution of 1815 it shall be underscored that the Polish Parliament-Sejm, following the Polish tradition going back at least

\footnotetext{
${ }^{70}$ The Polish Constitution of 3rd May 1791 had 3728 words divided into 11 main articles preceded with a preamble and ended with a declaration of the representatives of the Parliament, whereas the Constitution of the Duchy of Warsaw consisted of merely 2622 words in 89 articles, ordered into 12 titles.

${ }^{71}$ They have respectively the following names: Of political relations of the kingdom (art. 1-10) General Guarantees (art. 11-34), Government (art. 35-84), Of the national representation (art. 85-137), The judicial order (art. 138-152), The armed force (art. 153-156) and General regulations (art. 157-165).

${ }^{72}$ Altogether the content of this normative act was therefore organised into 16 autonomous entities within a two-level structural division.

${ }^{73}$ In terms of words it had 3147 words, i.e. $70,6 \%$ of the total bulk of the Constitution.

${ }^{74}$ Cf. Handelsman (1915, p. 19) and Izdebski (1990, pp. 200-201).

${ }^{75}$ See art. 141 sentence 1 of the Constitution. All the following numbers of the articles in this subchapter refer to the 1815 Constitution of Kingdom of Poland.

${ }^{76}$ Cf. art. 151.

${ }^{77}$ Art. 43.
} 
to the XV century, was divided into two chambers: Deputies' Chamber (Izba Poselska) ${ }^{78}$ and Senate (Senat). ${ }^{79}$ However what was a veritable breakthrough for the entire Polish constitutional history was the regulation of art. 130. It enabled anyone who was: "paying any amount of contribution upon his estate" to participate with suffrage rights in communal assemblies, which were responsible for choosing 51 out of 126 members of the Deputies' Chamber (Izba Poselska). ${ }^{80}$ Those two chambers of the Parliament did not have a right to initiate legislation though, but were voting on the projects of laws submitted upon the King's order, be it previously elaborated by State's Council (Rada Stanu) or not. ${ }^{81}$

It was this State's Council (Rada Stanu), consisting of a smaller Administrative Council (Rada Administracyjna) and of General Assembly (Zgromadzenie Ogólne) as plenary body ${ }^{82}$ which together with the king's representative was to "administer the affairs of the kingdom in the King's name, during his absence."83 — what obviously due to the presence of the tsar in St. Petersburg was a normal situation. State's Council (Rada Stanu) was subordinated to Parliament by the obligation to present general report on its activities, ${ }^{84}$ which used to be heavily debated in Deputies' Chamber (Izba Poselska), creating a suitable opportunity for the parliamentary opposition to severely criticise the government of the Kingdom. Another example of a formal subordination of State's Council (Rada Stanu) under the Sejm's scrutiny was the juridical cognition of Parliament's Court (Sąd Sejmowy) over the infrigments of the Constitution and ordinary laws by the Ministers of State's Council (Rada Stanu) and other executive clerks. ${ }^{85}$

Those backbone regulations are preceded by the critical for the position of the Polish state first title of the 1815 Constitution. It formally stipulated a dependent position of the Kingdom, which was to be "for ever united to the Empire of Russia". ${ }^{86}$ The nature of this unification appeared according to art. 3 to be limited to the personal union, with the Russian tsar being simultaneously the king of Poland. ${ }^{87}$

\footnotetext{
${ }^{78}$ Art. 118 , i.e. $40,47 \%$ of the deputies.

${ }^{79}$ Art. 108.

${ }^{80}$ From this period there are known examples of Polish peasants who were elected for public functions, such as assessors, cf. Mencel (1968, p. 651), yet there were no peasants among the representatives to Sejm and this political breakthrough associated with granting political rights to peasants was not appreciated in broader circles, cf. Mencel (1968, p. 657).

${ }^{81}$ Art. 96, 102.

${ }^{82}$ I.e. Council of administration-cf. art. 65: "The council of state shall be divided into a council of administration and a general assembly". Council of administration was itself composed of "the heads of the five departments of government and of other persons specially appointed by the King" (cf. art. 66).

${ }^{83}$ Art. 64.

${ }^{84}$ Art. 92.

${ }^{85}$ Art. 82.

${ }^{86}$ Art. 1.

${ }^{87}$ Art. 3 stated that: "The crown of Poland is hereditary in our person and that of our descendants, heirs and successors according to the order of succession established for the Imperial throne in
} 
In case of his absence in the Kingdom of Poland, the tsar shall nominate his representative ("Namiestnik"), being either a Russian Prince of the Blood or a Polish citizen, ${ }^{88}$ laying down at the same time the extent of his prerogatives. ${ }^{89}$ Nonetheless, it was also regulated that the foreign policy is common for both countries, ${ }^{90}$ yet the tsar could allow the Kingdom to be party to the international treaties. $^{91}$

Following those stipulations of the opening title of the Polish 1815 Constitution, it is a very controversial issue to what extend the Kingdom of Poland could be considered to have been an independent subject of international law. It appears right to state that the historical examples of the treaties signed by the Kingdom of Poland $^{92}$ are a vital indication that it was not merely an intrinsic part of the Russian Empire, but was at least partially recognised internationally. ${ }^{93}$

Another highly significant part of the stipulations was a combination of individual and collective human rights incorporated into title II of the Polish 1815 Constitution. They encompassed i.a. religious freedom and prohibition of civil and political discrimination on religious grounds, ${ }^{94}$ freedom of print, ${ }^{95}$ freedom from unsubstantiated persecution and illegal imprisonment, ${ }^{96}$ personal freedom, ${ }^{97}$ protection of property, ${ }^{98}$ guarantee of the usage of Polish language in public affairs ${ }^{99}$ and sole access of the Poles to the public, be it civil or military, functions. ${ }^{100}$ There was a guarantee of the responsibility of the civil servants for professional activities as public functionaries as well as a vague proclamation that "The law shall protect every class of citizens alike, without regard to their rank or condition". ${ }^{101}$ Those

Russia". It is worth noting that tsar Nicholas I Romanov undertook his separate coronation in Warsaw on 24th May 1829, which, formally speaking, was the last coronation on the polish soil. ${ }^{88}$ Art. 5 and 6.

${ }^{89}$ Art. 7.

${ }^{90}$ Art. 8. For Mażewski (2014, p. 63) it is a clear testimony that between those two countries there existed a real union. Some earlier authors claimed that it precluded the Kingdom of Poland from attaining a position of a subject of international law: e.g. Dembski (1974, p. 172), see in this respect considerations below.

${ }^{91}$ Art. 9.

${ }^{92}$ As for instance a convention between Russian Empire, Polish Kingdom and Prussia upon the regulation of relationships of mutual trade and navigation, signed in Berlin on 11th March 1825, cf. Mażewski (2014, pp. 66-69).

${ }^{93}$ Mażewski (2014, p. 70) rightly concludes that it also cannot be considered to have been a fully-fledged subject of international law.

${ }^{94}$ Art. 11.

${ }^{95}$ Art. 16.

${ }^{96}$ Art. 21, 23.

${ }^{97}$ Art. 24.

${ }^{98}$ Art. 26.

${ }^{99}$ Art. 28.

${ }^{100}$ Art. 29.

${ }^{101}$ Art. 17. 
rights and liberties were not restricted to polish citizens since: "Every legitimated foreigner shall enjoy the protection of the laws and the advantages which they secure on the same footing as the other inhabitants". ${ }^{102}$

Finally, the closing title of the 1815 Constitution contains some transitional and organisational regulations, of which two as being highly important merit closer attention: art. 160, which preserved certain polish civil and military awards and art. 165 which, read a contrario, kept in force all the previous statues which were not contrary to the adopted Constitution. ${ }^{103}$ Therefore it is right in my view to speak about the legal continuity between the Duchy of Warsaw and the Polish Kingdom. ${ }^{104}$

It is important to note that from the formal point of view this Constitution has to be perceived as being one of the most liberal in post-congress Europe, ${ }^{105}$ giving suffrage rights to more than 100,000 people, including peasants ${ }^{106}$ and numerous civil freedoms. ${ }^{107}$ However, it was perennially infringed by the Russian authorities, being reduced to nothing more than an instrument of propaganda, attesting to the alleged liberal approach of the Russian tsar in respect to the Polish Kingdom. ${ }^{108}$ A blatant example of such infringements was the notorious curbing of the independence of the judiciary, especially by not-appointing judges and replacing them with dependent deputy-judges, ${ }^{109}$ eradicating the freedom of the press ${ }^{110}$ or even

\footnotetext{
${ }^{102}$ Art. 32 sentence 1 .

${ }^{103}$ Due to this regulation some of the most vital French regulations, introduced in the Duchy of Warsaw, such as Napoleon's Civil Code could be maintained. This legislation in some respect still influences the polish legal system (cf. in this respect e.g. a judgment of Polish Supreme Court from 27th June 2013 in case III CZP 29/13 upon the applicability of art. 713 of French Civil Code for current legal obligations) what could not be possible, had it not been for the aforementioned art. 165 .

${ }^{104}$ Roztworowski, (1915, pp. 34-35) who even goes so far as to state (p. 35) that: "The Constitution of Duchy of Warsaw and decrees from the previous period are not canceled, but to the contrary, expressis verbis upheld". It has to be added that it was a situation which apparently Alexander I Romanov strived to achieve at least since 1811, once again taking over the central territories of former Poland-Lithuania.

${ }^{105}$ Kutrzeba (1916, p. 24), where he speaks about "the most liberal Constitution which any European country had at this time".

${ }^{106}$ This estimation is given according to a detailed overview of the scale of the political activity of the society of the Kingdom of Poland presented by Mencel (1968, p. 646).

${ }^{107} \mathrm{Cf}$. considerations above.

${ }^{108}$ Bardach et al. (1979, p. 186). As a very accurate appears the statement made by Fryderyk Skarbek, Królestwo Polskie do rewolucyi listopadowej, vol. I, Poznań 1877, p. 46 that tsar Alexander I was "mistaken, when he understood, that he can win over Poles by merely stipulating freedoms without any guarantees of its respecting”, cf. Szymaniec (2014, pp. 286-292).

${ }^{109}$ Witkowski (1988).

${ }^{110} \mathrm{By}$ the decisions issued on 22th May and 16th June 1819 the representative of the tsar, general Józef Zajączek introduced a preventive censorship of the press in a blatant infringement of art. 16 of the Constitution, cf. Gąsiorowska (1916, pp. 53-73).
} 
more outright by not convoking Sejm within the time limits specified in the Constitution $^{111}$ or making confidential its proceedings. ${ }^{112}$

That instrumental treatment of the Polish 1815 Constitution as merely a propaganda tool, which contradicted the stipulations of the Vienna Congress in respect to Poland, became quickly known. ${ }^{113}$ Moreover, it has been recognized that the 1815 Constitution was used as fake instrument to appease the Polish society ${ }^{114}$ and was nothing more than a good will of the Russian tsar, ${ }^{115}$ who one-sidedly granted it to the Polish Kingdom. ${ }^{116}$ This approach is fully consistent with the view of the Russian politicians who constantly feared the polish striving for independence. ${ }^{117}$

Interestingly, the Polish Constitution of 1815 was not-unlike some other XIX-century Constitutions ${ }^{118}$ — subject to any more extensive legal, philosophical

\footnotetext{
${ }^{111}$ According to art. 87 the ordinary Sejm "shall meet once in every two years at Warsaw" whereas the Sejms were convoked only in the years $1818,1820,1825$ and 1830.

${ }^{112}$ What was introduced due to the one-sided amendment of the 1815 Constitution by Alexander I Romanov on 13th February 1825.

${ }^{113}$ An anonymous French author commenting the outbreak of an uprising of the Polish 1830 November Uprising wrote: “L'empereur de Russie n'a pas voulu comprender l'esprit des dispositions du congrès de Vienne l'égard des Polonais; il n'a pas même respecté la lettre de la loi", cf. s.n., La Pologne et le Congress de Vienne, Paris 1831, p. 8, source retrieved by the author from Bibliothèque Polonaise de Paris (source number: BPP FA 30137 II) and made available on the internet platform of the project under: http://sources.reconfort.eu/. The same anonymous author of the text goes on as to say that: “(...) mais les empereurs russes en se jouant continuellement de ces obligations, en violant sans cesse la constitution qu'ils avaient juré de respecter, l'ont tout-à-fait anéantie." (s.n., La Pologne et le Congress de Vienne, Paris 1831, p. 9), even though "les puissances européennes ont reconnu le droit qu'avaient les Polonais à former une nation séparée" (s.n., La Pologne et le Congress de Vienne, Paris 1831, p. 10).

${ }^{114}$ D'Herbelot (1830, p. 31) source retrieved by the author from Bibliothèque Polonaise de Paris (source number: BPP FA 30138) and made available on the internet platform of the project under: http://sources.reconfort.eu/: “La Russie, voulant avoir des vassaux, n'a donné à l'amour-propre national qu'une satisfaction dérisoire; elle a mesuré sordidement ce qu'elle concéderait de liberté à la Pologne, et elle a fait la dose si petite qu'autant aurait valu la supprimier tout-à-fait".

${ }^{115}$ D'Herbelot (1830, p. 31): “La Pologne ne peutrester telle que 1815 l a constituée: car, dans cet état, elle n'existe que sous le bon plaisir de l'empereur, et n'est d'aucune utilité pour l'Europe". ${ }^{116}$ D'Herbelot (1830, p. 27), where the 1815 Constitution is referred to as: ,la charte octroyée par Alexandre." It starkly contrasts i.e. with the case of the Belgian Constitution 1831 which was of popular origin and imposed far-reaching limitations on the power of the monarch, who, upon accepting the crown, had to concede to them - cf. in this respect: Deseure (s.a., pp. 119-120).

${ }^{117}$ Very ilustrative appears the formulation of Karamzin $(1818$, p. 10) "Les Polonais légalement constitués en un people distinct et souverain, seraient plus dangereux pour nous que ne le peuvent être les Polonais sujets russes" (retrieved by the author from Bibliothèque Polonaise de Paris (source number: BPP 344, pos. 6) and made available on the internet platform of the project under: http://sources.reconfort.eu/.

${ }^{118}$ As was for instance the case with i.e. with Statuto Albertino, where "The need to discuss public matters created a real 'community of the word' and of print media", cf. Mecca (s.a., pp. 177-183).
} 
or journalistic commenting by the contemporaries. There can hardly be found any study books or monographs devoted to the legal analysis of this normative act stemming from the $1815-1830$ period. ${ }^{119}$ This situation renders it necessary to seek the legal positions towards this Constitution in dispersed stances made by the participants of the public life of the Polish Kingdom 1815-1830.

In this public life of the Kingdom it is important however and for the purpose of this article also sufficient to discern two major currents. The first one perceived the 1815 Constitution as a magnanimous gesture of the Russian tsar who kindly granted it to the Kingdom and is free to revoke it anytime he pleases. ${ }^{120}$ Consequently, the inhabitants of the Polish Kingdom shall strive to peacefully cooperate with the Russian authorities, utilising the methods available to them within the existing political situation. ${ }^{121}$ The second major current treated the Constitution as a mutual contract between the tsar (being simultaneously the polish king) and the polish society. ${ }^{122}$ Based on those premises the representatives of this approach voiced their disapproval at every infringement of the highest normative act of the Kingdom. ${ }^{123}$ After a fierce battle between those two attitudes on the Sejm in the year $1820^{124}$ this liberal, opposing current started gaining momentum and became a catalyst for the military November uprising in $1830 / 1831$.

\footnotetext{
${ }^{119}$ Just before closing the editorial works upon this paper the author did encounter in the Central Archives of Historical Records in Warsaw (source number: fonds 391, number 1252a) a manuscript of the treaty written by Tadeusz (?) Ostrowski, Konstytucja Krolestwa Polskiego z r. 1815 in October 1823, being an attempt of the legal commenting upon this normative act. It is to be made available on the internet database of the project under: http://sources.reconfort.eu/ and possibly referred to in subsequent publications.

${ }^{120}$ Cf. e.g. Skarbek (1821), especially p. 121 (with a statement: "the reincarnated, dear name of the homeland, returned due to the liberties of the grateful king" a source retrieved and made available on the internet platform of the project under: http://sources.reconfort.eu/.

${ }^{121}$ Such as parliamentary election in order to choose the best possible representatives to Sejm with the purpose of creating good laws, cf. Skarbek (1820), a source retrieved and made available on the internet platform of the project under: http://sources.reconfort.eu/. It is worth stressing that such an approach was radically different than the one prevailing during the Polish Commonwealth, when, as A. Tarnowska observed: "no thesis of the exclusive sovereignty of the monarch was ever raised in Poland, because this would have never been approved", cf. Tarnowska (s.a., p. 249).

${ }^{122}$ Niemojowski (1818, p. 5), who admonished: "Our government shall, following the fatherly inspiration of our blessed king, our beloved Lord, following strictly the granted to us Constitutional Charter, strive to increase the number of inhabitants of our country, it shall remove the obstacles (...) which are various arbitrary and unconstitutional burdens (...)", cf. also Dyaryusz Seymu Królestwa Polskiego 1818, vol. III, Warszawa 1818, p. 51.

${ }^{123}$ Cf. Dziennik posiedzeń izby poselskiej w czasie Sejmu Królestwa Polskiego w roku 1820 odbytego, Warszawa 1820.

${ }^{124}$ Skowronek (1995) and his source: Julian Ursyn Niemcewicz, Pamiętniki, volume I, which according to J. Skowronek it is to be available in the Princes Czartoryski Library, the source number: 3514 IV.
} 


\section{Regulations in the 1815 Constitution Concerning the Criminal Law}

The decisive constitutional normativity of the Constitutions as developed in the end of the 18th century expressed itself i.a. as the requirement that statutory law should be congruent with the hierarchically higher placed text of a written Constitution. ${ }^{125}$ This idea - of a legal system as a system combining various levels of normativity where regulations on each level have to be in conformity with that placed abovehas persevered, be it significantly more sophisticated, ${ }^{126}$ until nowadays. Consequently, the particular laws, such as regulations in the field of private or criminal law can be perceived as an extension, development or concretisation of the constitutional principles.

Yet there is another important aspect of this hierarchical structuring of the legal system, namely that a written Constitution shall lie down the basic principles for all branches of law in order to enable to verify their "constitutionality", since otherwise this verification process could not effectively take place. Correspondingly, in order to comprehend the development of this decisive constitutional normativity in the field relevant for this paper it is necessary to outline those regulations of the 1815 Constitution of the Kingdom of Poland which pertain to the criminal law.

Careful perusal of this normative act gives little reason to expect that any more detailed regulations concerning the criminal law could be encountered here, since already in the Art. 4 its narrow regulatory scope appears to be laid down very precisely: "The Constitutional Charter determines the manner, the principle, and the exercise of the sovereign authority". Yet no later than in Chapter II of the Constitution, labelled "General Guarantees" lying down - as it has already been mentioned above - the basic rights in the Kingdom of Poland there are incorporated numerous regulations concerning both the criminal procedure as well as the substantive criminal law itself. Above all there is a towering proclamation of the Art. 17: "The law shall protect every class of citizens, alike, without regard to their rank or condition." More specifically for the field of criminal law, the Art. 23 states that: "No man shall be punished except in conformity with the existing laws and by the decree of the competent Magistrate." Further, Art. 26 in its third sentence declares that: "Any person attempting to appropriate the property of another shall be held to be a disturber of the public peace and punished accordingly."

\footnotetext{
${ }^{125}$ Müßig (2016, p. 1), who also conceptualised and explained there the term of "Decisive Constitutional Normativity" (DCN) as well as Ulrike Müßig, Preface, p. 2, where she observes that with the American Revolution: "constitutional law and other kinds of law were conceptually differentiated".

${ }^{126}$ Encompassing nowadays not only the vertical relationship between the written statutes and the Constitution, but also between the statutes and the executive acts or the Constitution itself and the acts of international law-cf. Olechowski (in print), cf. this book, pp. 238 and Footnote 14 who discusses the views of Alfred Verdross as the supporter of the monistic theory of national and international law.
} 
Apart from those provisions, there can also be found some regulations concerning the legislative process in the field of the criminal law. Art. 90 expressly highlights the competence of Sejm (understood as the gathering of the two chambers of the polish Parliament) to consider the projects i.a. in the field of the penal legislation, ${ }^{127}$ for which, according to art. 98 of the Constitution, separate Commissions should be established. ${ }^{128}$

More importantly for the very question of the precedence of the Constitution, the already discussed Art. 165 stated that: "All anterior laws and institutions which maybe Contrary to the present charter are hereby abrogated". This stipulation, combined with the regulation of Art. 55 and $82^{129}$ which introduced personal responsibility of the members of regency and ministers for every act infringing the Constitution, were the most far-fetched regulations concerning the supremacy of this legal act, even though they were not explicit in their formulations. ${ }^{130}$

Analysing the Polish 1815 Constitution in a historical perspective, it has to be highlighted that its regulations in the matters of criminal laws were significantly more far-reaching than both the Polish Constitution of 3 May 1791 as well as the Constitution of the Duchy of Warsaw. The first one did not even stipulate formal equality before the law and was oblivious to such rudimentary principles of

\footnotetext{
${ }^{127}$ According to this statute: "The diet [i.e. Sejm-M. Byczyk] shall take into consideration all proposed civil, criminal, or administrative laws; referred to it by the King, through the council of State [Rada Stanu-M. Byczyk]. It shall deliberate on all' proposed modifications or alterations of the duties of public offices and constitutional powers, such as those of the diet, the council of State, the judicial order, and the government commissions; such change or modification being referred to its consideration by the royal authority".

${ }^{128} \mathrm{Cf}$. art. 98: "For the discussion of these drafts, each chamber appoints three commissions of examination, which are composed in the senate of three members, and in the chamber of nuncios of five, to wit:

Commission of finances.

Commission of civil and criminal legislation (...)".

${ }^{129} \mathrm{Cf}$. art. 55: "The members of the regency of the kingdom shall be responsible in their persons and in their property for whatever they may have done contrary to the Constitutional Charter, or to the laws".

Art. 82: "The heads of departments and the members of government commissions are answerable to the Sad Sejmowy for every infraction of the Constitutional Charter and the royal decrees of which they may have been guilty".

${ }^{130}$ This ambiguity found its echo in the secondary literature, especially as Roztworowski (1915, pp. 34-35) spoke about "new polish king Alexander, who from his own will granted to it a octroyed Constitution, and even, properly speaking, two constitutions: one, a provisional one, laid down already in Vienna, with the date 25th May 1815 under the name "Bases de la Constitution", second, final, with the date of 27th November 1815 in Warsaw, which entered into force on 24th December of that year." A final clarification of this issue took place with the resolution of the General Assemby State's Council (Zgromadzenie Ogólne Rady Stanu) on 18 March 1816, which stated that due to the promulgation of the 1815 Constitution the Principles of the Constitution lost their normative force.
} 
criminal law as nullum crimen sine lege, ${ }^{131}$ already explicitly recognised in the French Declaration of the Rights of Man and of the Citizen. ${ }^{132}$ The second one was limited to formalising the political order of this newly established, Napoleonic state and did go little beyond founding formal equality before the law, ${ }^{133}$ stating the openness for the public of the judicial cases in criminal matters and reserving the competence to enact new criminal legislation for the Main Sejm (Sejm Główny), the Polish Parliament of that time. ${ }^{134}$ Furthermore, it has to be stated that in the 1815 Constitution of the Kingdom of Poland the regulations concerning the criminal law were noticeably more comprehensive and detailed than in the paradigmatic for the entire post-congress Europe French Constitutional Charter of 1814. ${ }^{135}$ This strengthens the thesis that it had not been inspired by this post-revolutionary piece of legislation. ${ }^{136}$

\section{The Enactment of the Polish Criminal Code of 1818}

The idea to create a modern codification in the field of the criminal law in Poland can be traced back at least to the Constitution of 3 May 1791, which in its VIII Sect. 6 in fine promised to codify both criminal and civil laws of the country. ${ }^{137} \mathrm{It}$ was revived on the Sejm of Grand Duchy of Warsaw of 1809, where in the resolution taken on 18 March $1809^{138}$ the application of the old Polish laws, and-on a

\footnotetext{
${ }^{131}$ Cf. Marcin Byczyk, Constituting the Polish Criminal Judiciary in the light of the Polish Constitutional debate of the late XVIII Centaury, speech held during the ReConFort Mid-term Conference on 20th September 2016.

${ }^{132} \mathrm{Cf}$. articles VII-IX of the Declaration of the Rights of Man and of the Citizen.

${ }^{133} \mathrm{Cf}$. art. 4 of the Constitution of the Duchy of Warsaw: "The slavery is abolished. All citizens are equal in front of the law. The estate of the people remains under the protection of the tribunals". ${ }^{134} \mathrm{Cf}$. art. 21 of the Constitution of the Duchy of Warsaw: "To it belongs the proper conferring in respect to the tax law, also the law upon the fiscal income, in respect to the amendments which are to be made in the civil or criminal legislation or in the monetary system".

${ }^{135}$ Which itself was very limited on the questions related to the field of criminal law, stating merely the principle of the public criminal trials (cf. art. 64) and freedom from an arbitrary prosecution (cf. art. 4).

${ }^{136}$ Similarly: Bardach et al. (1979, p. 368), opposite view was presented by Izdebski (1972, p. 132) who wrote that the Constituiton: „cleraly patterned itself upon the Constitutional Charter of Ludwig XVIII".

${ }^{137}$ Ustawa Rządowa, czyli nowa Konstytucya Polski, Volumina Legum, vol. IX, p. 224: "We command that a new code of civil and criminal laws be drawn up by persons designated by the Sejm." There however had been earlier requests to change and codify both the substantial as well as procedural criminal law in the Kingdom of Poland starting from 1740 and subsequently clearly expressed in the resolution of the Sejm from the year 1776 (Volumina Legum, vol. VIII, p. 543) cf. Michalski (1958, p. 287) et seq, Borkowska-Bagieńska (1986) and Szafrański (2007).

${ }^{138} \mathrm{Cf}$. the Diary of the Sejm 1809 to be available in the Central Archives of Historical Records in Warsaw, source number: Fonds 182-Sejm Księstwa Warszawskiego i Królestwa Polskiego; see on this matter: Śliwowski (1958, p. 14), on whose book—where possible-I have essentially relied
} 
subsidiary basis - of the Prussian legislation was stipulated: "as long as a proper for the Duchy of Warsaw Criminal Code cannot be elaborated". ${ }^{139}$

In the dramatically changed political situation, with the establishment of the Kingdom of Poland after the Vienna Congress in the year 1815, tied by a real union to the Russian Empire, the works on a new Criminal Code were seriously commenced only after the Russian tsar via the minister or secretary of state of the Polish Kingdom made a formal request to the government of the Kingdom to prepare such an act in the year $1817 .{ }^{140}$ One of the possible cardinal reasons for such a decision was the disparity existing between different laws which were in force in the Kingdom, encompassing Prussian and Austrian criminal statutes, what in turn significantly hampered the efficacious functioning of the criminal judiciary, ${ }^{141}$ another: the long standing yearning of the Polish society for a modern codification of criminal law. ${ }^{142}$

It is certain however that the idea of elaborating an original Polish Criminal Code was abandoned due to the explicit decision of the governor of the Kingdom of Poland, Józef Zajączek, from 29 December 1817 and replaced with the subsequent endeavours to adopt the Austrian Criminal Code of 1803, after modifying it as to fit into the Polish social, legal and intellectual background. ${ }^{143}$ The ensuing, hastily works led to preparing-within less than 3 months - a complete project of a criminal codification which was submitted to the Polish Sejm in a printed version on 30 March 1818, after its final acceptance by State's Council (Rada Stanu)

\footnotetext{
(particularly for the descriptive sections) in this and the next fragments of the paper, being also very indebted to J. Śliwowski for his valuable footnotes, which proved very helpful when investigating into the topic of this paper and the publication of some of the sources related with the codification process of the year 1818 .

${ }^{139}$ Cited according to Śliwowski (1958, p. 14). Such an attempt of enacting a Criminal Code was undertaken in the year 1811, where a translation of the French Criminal Code, with absolutely slight changes (cf. Kodeks przestępstw i kar przetłumaczony z francuskiego z zlecenia JW. Jasińskiego, Warszawa 1811) was proposed and rejected as the Criminal Code for the Duchy of Warsaw. See in depth on this issue: Handelsman (1914).

${ }^{140}$ Barzykowski (1883, vol. I, p. 130) gives the date when those works were began, namely: 17 th of September 1817, writing that on this day: "the minister secretary of state for the first time convened the council of the ministers so that it shall prepare the projects of the laws", yet without giving sources for this claim. Cf. also Hoffmann (1831, pp. 179-180) and Śliwowski (1958, pp. 39-40).

${ }^{141}$ Cf. Hube (1863, pp. 5-6).

${ }^{142}$ Cf. Michalski (1958).

${ }^{143}$ The exact reasons for such a decision remain unknown. While Śliwowski (1958, p. 40), writing in the times of communist regime speculated about the comfort of using foreign legislation which "protected the class interests of the ruling estate", it is much more probable that due to the lack of qualified polish lawyers there was no intellectual capacity to realise such a work within a reasonable period of time. This decision was also criticised subsequently by the polish lawyers since "book I and II of the Code 1818 was in its greater part transformed into a simple translation of its original", cf. Hube (1863, pp. 20-21). It indeed was to a great extend merely a translation of the Austrian original.
} 
17 days earlier. ${ }^{144}$ During the meeting of State's Council (Rada Stanu) on the 30 March it was also decided that the discussion on the project in Sejm shall not exceed 6 days. ${ }^{145}$ Such a mode of proceedings significantly limited the possibility of any broader public debate and it renders it necessary to seek echoes of the discussions on respecting the constitutional principles in the to-be-enacted Criminal Code in the speeches of the members of the Deputies' Chamber and of Senate.

Consequently, it is necessary to analyse the parliamentary works of the Sejm in the year 1818. In the gathering of the Parliament of Kingdom of Poland in the year 1818 the project itself was worked upon in two separate stages. During the first stage it was analysed by the joint legislative Commissions of the Sejm; only later, at the second stage, it was debated on the general forum of the Sejm. ${ }^{146}$ During this first phase there had been formulated altogether 58 propositions of amendments to the project, submitted to State's Council (Rada Stanu) for acceptance, out of which some are directly related with the questions of the precedence of Constitution and the division of powers. ${ }^{147}$

First of such amendments pertained to the proposition to change the wording of article 98 of the project of the Criminal Code in order to treat as a crime of abuse of power cases where a minister countersigns a decree of the king or of the governor which is "against Constitution and the laws" as well as to treat as such crimes the cases of issuing ordnances "against the regulations of the Constitution, organic statutes, laws or the resolutions of the king or king's representative" 148 by the ministers or members of the governmental commissions. The second proposed amendment concerned adding formulation in the aforementioned article that judges were to become culpable of the abuse of power if they neglected to act correctly and diligently, but at the same time did not curb the "protected in the article 138 and 139 of the Constitution independence of the judiciary". ${ }^{149}$ Third likewise interesting amendment of the joint legislative Commissions was related with the open wording of the statute on robbery, which after mentioning different ways of acquiring

\footnotetext{
${ }^{144}$ According to Śliwowski (1958, p. 47) this project can be found in Central Archives of Historical Records in Warsaw, source number (according to current numeration): I Rada Stanu Królestwa Polskiego, microfilm A-22892.

${ }^{145}$ I.e. 3 days on the forum of the Sejm and 3 days in the joint legislative Commissions, cf. Protocol of the meeting of State' Council (Rada Stanu) on 30th March 1818, cited according to Śliwowski (1958, p. 463). It is symbolic for the role and the position of the Sejm in the Kingdom of Poland.

${ }^{146}$ Śliwowski (1958, pp. 157-161).

${ }^{147}$ Out of which 7 were rejected, cf. Protocols of the meetings of State's Council (Rada Stanu) on 16th and 17th April 1818, cited according to Śliwowski (1958, 465-473). The plenary discussions in Sejm concerned only this amended version of the project since it could not introduce any amendments to the project itself.

${ }^{148}$ Cited according to Śliwowski $(1958,466)$.

${ }^{149}$ Even though the speaker invokes the independence of the judiciary, the real sense of this change is unclear; maybe the proposed amendment was written down with a spelling error and in fact the intention of the joint Commissions was to propose: "curbing" instead of "not curbing". Cited according to Śliwowski (1958, p. 466).
} 
possession of the goods ended with "etc". Such an open-ended statute was rejected by the Commission which wanted to prevent "arbitrariness of the judges" and demanded that the addition "etc." shall be dropped. ${ }^{150}$ This last proposed amendment appears to be very significant since it testifies to the awareness of the representatives to the Parliament ("Sejm") of the high value of strict interpretation of the legality principle, an attitude that was even going beyond the regulations of the Constitution of 1815, being itself still far from explicitly acknowledging the nullum crimen sine lege certa doctrine. Yet it was, together with the second amendment presented above, rejected by State's Council (Rada Stanu) and did not become binding law. ${ }^{151}$

This aspect of the judiciary as the constituted power, with the endeavours to bind the judges to the greatest possible extend by the formulations of the codified statutes was raised once again during the second phase of the legislative process, namely in the discussions on the forum by the representatives in the Deputy Chamber of the Sejm. ${ }^{152}$ Closer scrutiny of this plenary debate, which took place on 18, 20 and 21 April 1818 reveals the fact that this was a recurrent leitmotif in the speeches of the deputies, starting from the very first discourse opening the debate on the project of Criminal Code pronounced by the Sejm Marshall, who highlighted the fact that: "In the constitutional countries the law should be clear and enlightened, leaving no freedom for a judge, since otherwise he will govern according to it and not according to the law and therefore he will become omnipotent". ${ }^{153}$

But the discussions were not limited to that problem. In fact, while fiercely debating upon the project of the Criminal Code, the representatives to the Parliament ("Sejm") were quite frequently resorting in their speeches to the Constitution. Those references were made in several contexts and in different manners.

First argumentative strategy ${ }^{154}$ is used to clearly manifest that the project of the Criminal Code is consistent with the 1815 Constitution of the Kingdom of Poland. Representatives to the Parliament ("Sejm") bring it forward in form of general

\footnotetext{
${ }^{150}$ Protocol of the meetings of Rada Stanu on 16th April 1818, cited according to Śliwowski (1958, p. 467).

${ }^{151}$ Protocol of the meetings of Rada Stanu on 16th April 1818, cited according to Śliwowski (1958, pp. 468-470). Only the first amendment was accepted into the enacted version of the Codex, cf. The Criminal Code of 1818 was published i.a. as Kodex karzący dla Królestwa Polskiego: z dodaniem praw kryminalnych późniey uchwalonych, reiestru porządkowego i alfabetycznego, przypisków wskazuiących artykuły związek z sobą maiące, Warszawa 1830, p. 22; this issue is also freely available in the Internet under: http://ebuw.uw.edu.pl/dlibra/docmetadata? $\mathrm{id}=210$, last accessed: 25.10 .2017 .

${ }^{152}$ Those discussions have not been so far analysed in the literature apart from a very brief chapter in the book of Śliwowski (1958, pp. 210-213), who essentially limited himself to the presentation of voices of five deputies, discussing mainly the questions of punishibility for crimes against religion in the light of the Polish 1815 Constitution.

${ }^{153}$ Diary of the Sejm of the year 1818 , Volume II, p. 49.

${ }^{154}$ I understand "argumentative strategies" in line with the very perception of argumentation typical for non-English languages as formulated by van Eemeren (2010, p. 26), i.e. as: "deliberate efforts to resolve a (real or projected) difference of opinion by convincing the addressee(s) in a reasonable way of the acceptability of the standpoints at issue".
} 
remarks: Wincenty Krasiński stresses the fact that the project "not only aims at securing the constitutional laws, but also will supply us with national laws, appropriate for our existence". ${ }^{155}$ For Ksawery Potocki the project is "inspired by the old and the new laws which we are familiar with (...) [and is] tailored to the Constitution" " and there is no punishment in form of "an expulsion from the country since Art. 25 [of the Constitution] states clearly that a sentenced person will serve his sentence in the Kingdom". ${ }^{157}$ Similarly Ksawery Potocki during session held on 20 April 1818 underlines: "Confiscation as contrary to the Constitution is at no place prevalent in the Codex." 158 For Mr. Hakenszmidt the project is "completely tailored to the Constitution, encompassing protection from the arbitrariness of the clerks", ${ }^{159}$ an argument repeated by Duke Komorowski ${ }^{160}$ and in a more general manner by Mr. Jasiński. ${ }^{161}$

The Constitution is also invoked for more specific issues, particularly in order to justify the punishment for certain crimes. ${ }^{162}$ Consequently, for Mr. Obniski "the religion of our ancestors is protected according to the Constitutional Charter (...) suicide is not forgotten and the polygamy and the perjury is counted as a felony". ${ }^{163}$ The division introduced in the project between the felonies, offences and misdemeanours is said to be coherent with Art. 146 and 149 of the Constitution. ${ }^{164}$

\footnotetext{
${ }^{155}$ Diary of the Sejm of the year 1818 , Volume II, p. 49.

${ }^{156}$ Diary of the Sejm of the year 1818, Volume II, p. 50. Similarly Mr. Faltz stresses that: "It is necessary that there would be an equal criminal law in the entire country, it is necessary that punishing laws were consistent with the constitutional charter", see Diary of the Sejm of the year 1818, Volume II, p. 109. It also is consistent with our "liberal Constitution" for Mr. Nowakowski, see Diary of the Sejm of the year 1818, Volume II, p. 106 and is "at no point contrary to the constitution", see the speech of Mr. Grabowski, Diary of the Sejm of the year 1818, Volume II,
} p. 121.

${ }^{157}$ Diary of the Sejm of the year 1818 , Volume II, p. 55.

${ }^{158}$ It is very interesting to note the semantics used by the representatives to the Polish Sejm in the year 1818. As it has been excellently observed by U. Müßig, one of the key issues for the development of the precedence of the Constitution in XVIII century was the fact the development of a new language, with different meanings of "constitutionality" and "legality", cf. Ulrike Müßig, Preface, p. 2, Footnote 23. This new constitutional semantics, which was a product of revolutionary upheaval in the second part of the XVIII centuries (cf. in this respect i.a. quotations from James Iredell Ulrike Müßig, Preface, p. 2, Footnote 12 and from Lord Bolingbroke, Stourzh (2017), cf. this book, p. 252, Footnote 11) testifies that a new era in the Polish constitutional discourse had already begun.

${ }^{159}$ Diary of the Sejm of the year 1818, Volume II, p. 67.

${ }^{160}$ Diary of the Sejm of the year 1818 , Volume II, p. 82.

${ }^{161}$ Diary of the Sejm of the year 1818 , Volume II, pp. 105-106.

${ }^{162}$ Such as for the crime of art. 91, which rendered it a prohibited act to help-without the knowledge of the state's administration - the local inhabitants of the Kingdom of Poland to leave the country in order to settle abroad, see speech of Mr. Oebschelwitz, Diary of the Sejm of the year 1818, Volume II, p. 129.

${ }^{163}$ Diary of the Sejm of the year 1818 , Volume II, p. 59.

${ }^{164}$ Diary of the Sejm of the year 1818 , Volume II, p. 54. However both those articles refer only to the general questions of organisations of the judiciary: According to art. 146: "There shall be civil 
Another specific issue is raised by those speakers who point to the fact that this project strengthens the constitutional freedoms. Among this group of speeches $\mathrm{Mr}$. Chmielewski praises the project for "being support for the constitutional freedoms". ${ }^{165}$ Further still: "it is a new honour for the project that it so clearly protects our Constitution". 166 The interesting issue concerning the constitutionally guaranteed equality before the law has been brought forward by Mr. Oebschelwitz, who pointing to the different criminal laws in force in Kingdom of Poland in the year 1818 (principally Austrian and Prussian) reaches the conclusion about the violation of the constitutional principle of the equality as laid down in Art. 17 of the Constitution, ${ }^{167}$ what urges to adopt a new, uniform Criminal Code. The same speaker stroke down the argumentation that a Criminal Code cannot be adopted unless a Code of Criminal Procedure has been elaborated by highlighting the necessity to develop the organisation of the judiciary as outlined in the constitutional order in the first place. ${ }^{168}$

All of that presented stances corroborate the fact that the vision of the Constitution as a primary and preceding normative act with which the Criminal Code should be coherent is clearly respected. Further still, there can be found a view that the Code shall also be interpreted and applied consistently with the Constitution: it is deputy Hakenszmidt who during the last day of the discussion on the project in the lower Chamber of the Sejm stresses the fact that the punishments which are projected in the Codex shall be meted out equally since "The constitutional statue does not distinguish between the estates". 169

The same argumentative strategies centring on the Constitution were also implemented by the adversaries of the project. Here it can also be distinguished between the general references to the Constitution, sometimes verging on purely rhetorical figures, and references made in very particular constitutional questions.

As for the case of the first approach, it was raised that the project, being inspired by the Austrian laws: "is contradictory to this spirit, which exists in our entire

tribunals and tribunals of the police, in every commune and in every town, to take adjudicate transactions not exceeding five hundred florins" and according to Article 149: "For criminal causes, and affairs of correctional police, there shall be several criminal tribunals in each palatinate".

${ }^{165}$ Diary of the Sejm of the year 1818, Volume II, p. 69.

${ }^{166}$ Speech of Mr. Linde, Diary of the Sejm of the year 1818, Volume II, p. 67.

${ }^{167}$ Diary of the Sejm of the year 1818, Volume II, p. 129.

${ }^{168}$ Diary of the Sejm of the year 1818 , Volume II, p. 129. This argumentation is very interesting, since already in the year 1814 Antoni Bieńkowski in his memorandum stated: "The change in the jurisprudence and its new organisation brings with it new propositions of the procedure. (...) the laws would not serve anyone for nothing if (...) their defence did not have a pointed way", (cf. the source retrieved by the author and made available on the internet platform of the project under: http://sources.reconfort.eu/: Antoni Bieńkowski, Uwagi Bieńkowskiego złożone na piśmie przeciwko zaprowadzeniu teraz nowej procedury i organizacji sądownictwa, 16.10.1814, The Princes Czartoryski Library source number: 5236 IV, 246-247.

${ }^{169}$ Diary of the Sejm of the year 1818, Volume II, p. 115. 
Constitution" 170 or simply "possibly less consistent with the Constitution then the laws in force at the moment". ${ }^{171}$ Clear illustration of the second type of the argumentation is provided by the speech of Mr. Biernacki, who advocates that there "can be no punishments for the persecutors as well as for the clerks, since the persecutors are judicial magistrates and the independence of the judiciary is the most beautiful characteristics of the Constitution". ${ }^{172}$ It is also rather the Code of the Criminal Procedure where "most clearly the blessed results for the Constitution can manifest themselves" 173 than the Criminal Code itself. However, there can be found even more radical voices, which implicitly charge the government with working in detriment to the country, in breach of the Constitution and attempting to vilify the project as insufficient to protect the constitutional interest of the Kingdom, since according to Mr. Krysiński "the offences are quite often a result of the activity of the government itself'. ${ }^{174}$ There are also fears whether the crimes which consist in breaching the Constitution will be unveiled at all. ${ }^{175}$

Other main argumentative strategy is based on underlining the fact that the project is congruent with the principles already recognised in the Polish Constitutionalism ${ }^{176}$. In this sense Mr. Obniski refers to the fact that: "the arbitrariness of the judge has been limited since the law clearly prescribes him what penalty for any kind of felony should be meted out, it can be neither a more severe nor a milder one than the one that the law prescribes". ${ }^{177}$ It is also the attitude of another representative in the Deputies' Chamber, Mr. Chmielewski, who calls for considering whether the project "will not serve the judges [as pretext] for arbitrariness". ${ }^{178}$ Even more surprising, according to yet another speaker ${ }^{179}$ the

\footnotetext{
${ }^{170}$ Speech of Mr. Krysiński, Diary of the Sejm of the year 1818 , Volume II, p. 111, being a possible allusion to the fact that the Austrian Empire at that time was not a constitutional monarchy.

${ }^{171}$ Speech of Mr. Krysiński, Diary of the Sejm of the year 1818, Volume II, p. 114.

${ }^{172}$ Diary of the Sejm of the year 1818, Volume II, p. 63.

${ }^{173}$ Speech of Mr. Krysiński, Diary of the Sejm of the year 1818, Volume II, p. 65.

${ }^{174}$ Diary of the Sejm of the year 1818 , Volume II, p. 63 . He continues as to say that the Criminal Code was to be enacted without investigating the reasons of the criminality, what had been "neglected by the Rada Administracyjna [Administrative Council]".

${ }^{175}$ Speech of Mr. Labędzki, Diary of the Sejm of the year 1818, Volume II, p. 87, similarly Mr. Godlewski, Diary of the Sejm of the year 1818, Volume II, p. 126.

${ }^{176}$ To avoid all the misunderstandings, I would like to clarify that I understand the term "Polish Constitutionalism" as referring to the set of ideas upon the basic regulations upon the division and organization of powers, sovereignty and political accountability as developed by the Polish politicians and intellectuals since the year 1764 .

${ }^{177}$ Diary of the Sejm of the year 1818, Volume II, p. 59.

${ }^{178}$ Diary of the Sejm of the year 1818 , Volume II, p. 69.

${ }^{179}$ In the available sources from the both Digital library of the Jagiellonian University (http://jbc.bj. uj.edu.pl/dlibra/docmetadata?id=275449\&from=publication, last access 18.11 .2016 ) as well as the Wrocław Digial Library the pp. 90-99 of the Diary of the Sejm of the year 1818 are missing, what makes it at this moment impossible to find out who that speaker was.
} 
acceptance of the project will lead to developing the principle of periodical revival of the Constitution, as established by the Constitution of 3rd May. ${ }^{180}$ For those speakers who are more positive towards the existing political state of the Kingdom of Poland the elaboration of the draft of Criminal Code can be seen as a further development of the Constitution, just as the reform of the courts' organisation. ${ }^{181}$

By the same token, the references to the inheritance of Polish Constitutionalism are also exploited by the adversaries of the project, who stress that it shall be rejected since it is "contrary to our way of thinking, our liberal Constitution". ${ }^{182}$ The large scope of the punishments that can be chosen from by the judges is criticised as being catalyst for their arbitrariness whereas in a "constitutional nation [it is the] law [which] should judge the misdemeanours and the crimes of a man". ${ }^{183}$

The semblance of those diverse argumentative strategies can be easily found in the discussion devoted to the project of Criminal Code in Senate. Yet here the number of the presented views was limited significantly owing to the simple fact that the discussion was taking place solely during one day, i.e. on 23 April $1818 .{ }^{184}$ Support for the project was manifested by pointing to the Constitution as its foundation $^{185}$ or praising leaving the apostasy of the catholic religion besides the scope of the criminalisation, ${ }^{186}$ while the scepticism towards the proposed codification was manifested by emphasising that the Code infringes the constitutional principle of equality before the law ${ }^{187}$ or the principle of the constitutional protection of the Christians religions ${ }^{188}$ or even highlighting the incongruity of the corporal punishments with "the nature of the constitutional government". 189

\footnotetext{
${ }^{180}$ Diary of the Sejm of the year 1818 , Volume II, p. 100 . It is not entirely clear what is meant here, however this reference to the Constitution of 1791 shows the continuity in the Polish Constitutionalism and awareness of its significance for the ordinary legislation.

${ }^{181}$ Speech of Mr. Wolicki, Diary of the Sejm of the year 1818, Volume II, p. 118.

${ }^{182}$ Speech of Mr. Szpietowski, Diary of the Sejm of the year 1818, Volume II, p. 89.

${ }^{183}$ Speech of Mr. Przyłuski, Diary of the Sejm of the year 1818, Volume II, p. 102.

${ }^{184}$ Diary of the Sejm of the year 1818, Volume III, p. 24.

${ }^{185}$ Speech of Mr. Wyszkowski, Diary of the Sejm of the year 1818, Volume III, p. 25.

${ }^{186}$ Speech of Mr. Matuszewicz, Diary of the Sejm of the year 1818, Volume III, p. 34.

${ }^{187}$ Speech of Mr. Gliszczyński, Diary of the Sejm of the year 1818 , Volume III, p. 30. His argumentation is based on a profound understanding of the project, since he points to the fact that the only way for poor people to avoid imprisonment was the corporal punishment of flogging, which, according to art. 219, 224 of the Criminal Code could shorten the sentence for up to 4 months for men and 8 months for women, whereas the richer perpetrators could make use of regulations of its art. 227, which will be discussed in detail below (cf. Fn 200).

${ }^{188}$ Speech of Mr. Gliszczyński, Diary of the Sejm of the year 1818, Volume III, p. 31. Little later the same speaker invokes the incongruity of the particular regulations of the project with "the spirit of our Constitution".

${ }^{189}$ Speech of Mr. Gliszczyński, Diary of the Sejm of the year 1818, Volume III, p. 32. Similarly it was pointed out that punishment in a form of a deportation, even though prevalent in the Austrian Code, was not incorporated into the project since it would be in breach of the art. 25 of the Constitution cf. speech of Mr. Gliszczyński, Diary of the Sejm of the year 1818, Volume III, p. 35.
} 
The above presented voices of the representatives in the gathering of the Polish Parliament in 1818 provide explicit evidence that 1815 Constitution was perceived as a supreme law which ordinary legislation has to respect and be consistent with. It also manifests the growth of the Constitutionalism perceived here as the legalist position demanding that the Constitution of the Polish Kingdom shall be respected any time and under any circumstances, ${ }^{190}$ the position which will be bolstered in the subsequent years by liberal opposition on the Sejm under the lead of the Niemojowscy brothers. For the purposes of this brief study it remains to be verified how this constitutional approach was reflected in the text of the enacted Criminal Code itself.

However before this question will be approached, is worth stressing that the Criminal Code of 1818 was not the only example of the Polish criminal legislation in the Kingdom of Poland. The important case of other regulation in this field is provided by the military criminal law. The statues which were in force here included the Criminal Code for the Polish Army of the Kingdom ${ }^{191}$ as well as the official translations of several French military statues, which were continued to be applied, irrespectively of the fall of the Duchy of Warsaw. ${ }^{192}$

The most characteristic feature of this part of the criminal legislation was the fact that it had been introduced without any formal legislative procedure and gave powers to an army's general in charge to enact further criminal statues for the soldiers under his command. ${ }^{193}$ Therefore, it constituted a grave violation of the constitutional principles, especially of the principle of the legality. It was also illustrative for both the political and the legal situation of the Kingdom of Poland where the military, under the leadership of the brother of Russian tsar Alexander I, Duke Konstantin Pavlovich had a special status, clearly violating the stipulated and proclaimed constitutional order.

\footnotetext{
${ }^{190}$ Equally well a term "legalism" could be applied, but due to the special context of the 1818 parliamentary debate, so much centered about verifying the compatibility of the to-be-enacted Criminal Code with the Polish Constitution 1815, this name appears to be more appropriate.

${ }^{191}$ Kodex kryminalny dla woyska polskiego or Artykuły do czytania woysku przed wykonaniem przysięgi. Instrukcya dla J.P.P. Oficerów Artylleryi, pełniących obowiązki audytorów, iako też dla officerów wszelkiéy broni, mogących bydź w potrzebie zastąpienia audytorów, Warsaw 1826.

${ }^{192}$ Prawa Karzące Woyskowe wypisane z Księgi Praw pod tytułem: Le Guide des Juges Militaires przez Xawerego Krysińskiego Audytora Generalnego Woysk Polskich przełożone z dołączeniem wzorów: skarg, inkwizycyi, wotowań i wyroków. w Warszawie w Drukarni Woyskowey 1824. Formally speaking, it was a selection and translation of the French laws prepared by a military official, de facto applied in the polish army of the Kingdom.
}

${ }^{193}$ Czyżak (2012, p. 5). 


\section{The Evaluation of the Congruity of the Criminal Code of 1818 with the 1815 Constitution of the Kingdom of Poland}

Having made the preceding considerations, it shall be analysed now to which extend the enacted criminal law ${ }^{194}$ was consistent with the presented regulations of the 1815 Constitution. Such an analysis appears to be particularly interesting bearing in mind the fact that it was almost a unique example of a codification of an entire branch of law in the Kingdom of Poland, ${ }^{195}$ and so far it has not been analysed more closely in this respect. ${ }^{196}$

The 1818 Code of Criminal Law generally accepted ${ }^{197}$ the principle of equality before the law, but it did encounter some minor exceptions. Most notably, according to the Art. 156, 160a-b of the Code, theft, nominally a misdemeanour, shall be considered as felony when it was committed through the servants to the detriment of their masters or by the apprentices to the detriment of their crafts' masters.

This regulation had been criticised both in the legal literature contemporary to the enactment of the 1818 Code $^{198}$ as well as in the only XX-century monographic study on the Code, being classified as a remnant of feudalism, infringing the formal equality before the law. ${ }^{199}$ Nevertheless, it has to be noticed that this particular mode of committing a theft stands out for abusing a special relationship of trust that should exist between a master and a servant and is getting close to embezzlement, what enables to understand treating it more severely. Similarly, it would be hard to consider the regulation of Art. 227 of the 1818 Criminal Code, which stated that: "If the fortune of a sentenced person is sufficient, the punishment of an arrest in a public house can be converted to a pecuniary punishment, but only there, where the

\footnotetext{
${ }^{194}$ The Criminal Code of 1818 was published i.a. as Kodex karzący dla Królestwa Polskiego: z dodaniem praw kryminalnych późniey uchwalonych, reiestru porządkowego i alfabetycznego, przypisków wskazuiących artykuły związek z sobą maiące, Warszawa 1830.

${ }^{195}$ It has been praised in the literature as being "besides the introduction of the Napoleon's Code the greatest event of the legal life on the polish soil in the first half of the XIX centaury", cf. Śliwowski (1958, p. 390).

${ }^{196}$ There can be found some valuable remarks upon the regulations of the 1818 Criminal Code which will be discussed below, such like art. 156 and 160, in Śliwowski (1958)—cf. pp. 281, 286$288,366-368,377$ but they were made from an entirely different perspective, i.e. in the light of the marxist perception of legal history as the fight between the estates.

${ }^{197}$ One of its very clear examples was delivered by art. 44 , which stressed that consequences of the punishments in form of civil death or loss of political rights did not reach the "innocent wife or husband".

${ }^{198}$ Dzierożyński (1830b, pp. 269-391) (partially wrong page numeration in the article), where (cf. pp. 374-378) the author directly refers to collision of the criminal law with general morality for the justification of his stance. This source has been obtained and scanned by the author and made available on the internet platform of the ReConFort project under: http://sources.reconfort.eu/.

${ }^{199}$ Śliwowski (1958, p. 281).
} 
law explicitly enables for such a change ${ }^{, 200}$ as such a type of an infringement, since even in the contemporary criminal law the delivered sentence can be commuted on numerous reasons and in very different manners. ${ }^{201}$

The Code of Criminal Law of 1818 respects the principle of nullum crimen sine lege poenali, ${ }^{202}$ expressed in its Art. 6: "As a felony, offence or misdemeanour only such a deed can be considered and punished, which according to this law has been found to be a felony, offence or misdemeanour". This rule was further supplemented by Art. 48-49, 60 and 225 which guaranteed that no other punishment can be meted out as that which had been explicitly mentioned in the Criminal Code. ${ }^{203}$

However there were notable exceptions to this approach: firstly, the rule was not respected in case of the misdemeanours, since art. 588 of the Code stated that "all the police misdemeanours which are not encompassed in this book shall be, according to their nature, considered to be belonging to one of the three chapters of this book und punished according to the punishments specified there."204 In case of the misdemeanours the 1818 Code also did not specify the required mental requirement of the perpetrator, but it hardly can be considered to be a breach of the legality principle. ${ }^{205}$ Nonetheless, to some degree this principle was infringed by two other statues, Art. 362 and 382 which stated that: "All other acts or omissions in respect to the security of human life, which endanger the natural and common duties of every man or which had been committed contrary to the explicit regulations of the law, which due to the number of their cases cannot be specified (...) shall be punished". ${ }^{206}$ Very similar approach can be found in the art. 186, which stated that: "Even though the cases of fraud and falsification due to their great

\footnotetext{
${ }^{200}$ Quite interestingly, among the lawyers of that time it was a contentious issue whether the perpetrator himself could choose what kind of penalty (i.e. between a public house and a pecuniary punishment) he will be serving [that was the view advocated by Brzeziński (1830)] while rejected by Hube (1829).

${ }^{201}$ In the contemporary European continental legal systems for every modification of a legally binding sentence a decision of judge is necessary and it is impossible to avoid serving a prison sentence by paying a given sum of money, cf. e.g. art. 60 or 155 of the contemporary Polish Kodeks karny wykonawczy (Dz. U. z 1997 r. Nr 90, poz. 557 z późn. zm.).

${ }^{202}$ Declared in the article 23 of the Constitution 1815, cf. above part II of the article.

${ }^{203} \mathrm{~A}$ further development of those regulations could be found in the specific provisions concerning the particular additional penalties, where, like in the case of a whipping post, it could be pronounced only when expressly stipulated by the law (cf. art. 36 of the Criminal Code 1818 in fine). ${ }^{204}$ Already the contemporary lawyers pointed to the fact that this regulation is contradictory to art. 1, 2 and 6 of the Criminal Code 1818, cf. Dzierożyński (1830a, p. 24), who wrote there about: "new doubts that sometimes grant almost unalloyed arbitriness to a judge".

${ }^{205}$ Jerzy Śliwowski considers that due to this omission it had to be assumed that negligence was sufficient as the minimal threshold of the mental attitude of the perpetrator, cf. Śliwowski (1958, p. 308), what appears to be a correct view.

${ }^{206}$ The wording of Article 382 was almost identic, yet aimed at offences against human body or health: "All other acts or omissions in respect to the security of human life, which infringe the natural and common duties of every man or which had been committed contrary to the explicit regulations of the law, which due to the number of their cases cannot be specified (...) shall be punished".
} 
number cannot be enumerated, the crime of falsification is committed when: (...)" giving only an exemplary and not complete list of the cases of frauds and falsifications.

Further, the 1818 Code did contain numerous provisions which elaborated the constitutional principle of the protection of the property, as specified in Art. 26 of the 1815 Constitution. This was guaranteed by a hoist of different offences specified in Chapter XI of the II Book of the Criminal Code. ${ }^{207}$

Interestingly, the Criminal Code of 1818 did contain a very specific provision about the criminal activity against the Constitution itself, namely Art. 247, according to which: "Who maliciously, by the means of scoffing writings or prints gives rise among the inhabitants of the country to disdain of the Constitution or attempts to give rise to such a disdain, shall be punished with arrest in a public house between 3 months and one year". This regulation clearly testifies how highly valued this legal act was, but also corroborates the persevering existence of an illusion that within the framework of the constitutional order of the Kingdom of Poland certain reasonable modus vivendi with the Russian Empire could be achieved.

Finally, it is worth stressing the fact that the Code already did adhere to several modern principles of the criminal law, such as cognitationis nemo patitur, ${ }^{208}$ going even beyond the text of the Constitution itself and possibly paving the way for the development of future Polish Constitutionalism and human rights. ${ }^{209}$

Briefly summarising the above presented implementation of the principles of the 1815 Constitution of Kingdom of Poland into the Criminal Code of 1818, it has to be stated that they did not amount to seriously contradicting the provisions of the adopted codification und could be easily revoked by a means of a simple subsequent amendment of this codification, being the more probable as the science of the Criminal law in Poland was starting to germinate at this time. ${ }^{210}$ Yet the changing political circumstances rendered the further development of the legislation in line with the established constitutional principles simply impossible.

\footnotetext{
${ }^{207}$ Art. 383-429. They were characterised by a very casuistic regulation, becoming the second longest chapter in the entire Criminal Code.

${ }^{208}$ Art. 26 stated explicitly that: "For bad thoughts, that is for a bad intention without any external acts or without intentional omission of what is prescribed by the law nobody can face criminal responsibility (...)".

${ }^{209}$ Especially, it could provide material for the development of the interpretation of the article 23 of the 1815 Constitution, which, as it has been stated above, provided that: "No man shall be punished except in conformity with the existing laws and by the decree of the competent Magistrate." so as to encompass the requirement of punishibility solely for external human acts which have at least an abstract potential to generate some harm to the legally protected interests, cf. in this respect the recent decision of the Polish Constitutional Court from 17th July 2014, SK 35/12 going in this direction (printed in: OTK ZU 7A/2014, poz. 74).

${ }^{210} \mathrm{~A}$ fact to which the establishing of the University of Warsaw on the 19 th November 1816 with a separate Faculty of Law and Administrative Sciences following the decree of Alexander I (cf.: Postanowienie naznaczające założenie Szkoły Głównej pod imieniem Królewskiego Uniwersytetu z dnia 7 (19) listopada 1816 r.-Dz.Pr.K.P. Volume XIII, Nr 51, pp. 90-95) contributed significantly.
} 


\section{Conclusions}

The above analysed proceedings concerning the elaboration and implementation of the Criminal Code of 1818, outstanding for being the first example of the Polish modern codification of substantial criminal law, did reveal profound respect for and importance of the regulations Polish 1815 Constitution. It manifested itself in the only available expression of the public debate in the given political circumstances, namely on the Parliaments' forum.

Even though there can be hardly found any printed essays or newspapers articles considering the issue of the congruence of the 1818 Criminal Code with the Constitution, undoubtedly among the representatives of the Polish voters in the Parliament ("Sejm") of 1818, irrespectively whether they were in favour of the codification-voters being proportionally the most numerous in that time in continental Europe - the idea that a Criminal Code should implement and develop the principles of this fundamental law was wholeheartedly accepted. Even though for the Russian authorities, including the tsar Alexander I Romanov, the Constitution was merely a pretence meant to appease the Polish society in its longing for independence, an utterly instrumental subterfuge, which could be one-sidedly amended ${ }^{211}$ and disrespected when convenient, for the Polish society and especially for the elected representatives to Sejm it was perceived as veritable supreme law in the country, which shall be respected and implemented by the ordinary legislation. This striking contrast between the legalist position of the Polish society and arbitrariness of the growing Russian despotism eventually incited the people of Kingdom to resort to the last possible means in defence of the 1815 Constitutionto a military uprising. ${ }^{212}$

It clearly shows the strength of the Polish Constitutionalism, not subdued by the difficult political circumstances and can be an inspiring example for our times.

\footnotetext{
${ }^{211}$ The best illustration of such a one-sided amendment is the addition to the Constitution by the Russian tsar Alexander I Romanov in a form of an "additional article to the constitutional law from 13 February 1825” („Arykuł dodatkowy do ustawy konstytucyjnej królestwa Polskiego z dn. 13 lutego 1825 r.") which made the debates of the Sejm secret, cf. Handelsman (1915, pp. 58-59).

${ }^{212}$ The most solemn expression of this attitude is the Manifesto of the Polish People, proclaimed on the Sejms session of 20.12 .1830 , i.e. 21 days after the outbreak of the November Uprising, specifying the reasons for this military resistance: cf. Sejm Królestwa Polskiego, Manifest Narodu Polskiego, p. 9: "Après tant d'affronts, a prés une violation si manifeste des guaranties jurées, violation qu'aucun gouvernement légitime, dans aucun pays civilise, ne se serait permise impunément, et qui, à plus forte raison, peut justifier notre soulèvement contre une autorité impose par la force, qui ne pensera que cette autorité a rompu toute alliance avec la nation, qu'elle lui a donné le droit de romper à chaque instant ses chaînes et d'en forger des armes?", which in paraphrased translation reads: "After so many violence, after the trampling of all the guarantees, which could justify not only an uprising against the power imposed by force, but which no rightful government in any civilised country could accept without punishment, who will not judge that the entire contract between the power and the nation has not been ruptured, that this nation became a slave, which any time could throw off the chains and convert them into weapons?".
} 


\section{Summary (Polish)}

Studium poświęcone jest zagadnieniu hierarchicznej nadrzędności Konstytucji Królestwa Polskiego z roku 1815. Artykuł podzielony został na trzy zasadnicze części.

W pierwszej, wprowadzającej części omówiona została geneza Konstytucji roku 1815. W opracowaniu objaśniono zagranicznemu czytelnikowi w oparciu o ustalenia polskiej literatury sekundarnej, opierając się na ustaleniach takich autorów jak S. Smólka, S. Askenazy, H. Izdebski (w zasadniczej mierze), D. Nawrot, że Konstytucja Królestwa Polskiego z roku 1815 została wykoncypowana jako narzędzie propagandowe $w$ zabiegach o poparcie polskiego i litewskiego społeczeństwa w trakcie wojen napoleońskich. Omówiono bliżej jej genezę, wskazując, iż była ona opracowywana począwszy od roku 1811 z udziałem polskich polityków orientacji pro-rosyjskiej, takich jak A Czartoryski, książę F. K. Drucki-Lubecki, M. K. Ogiński, czy L. Plater. Po przełomowym zwycięstwie szóstej koalicji z udziałem Alexandra I nad wojskami francuskimi, stała się kamieniem węgielnym odrodzonego na Kongresie Wiedeńskim, wieczyście połączonego z Cesarstwem Rosyjskim Królestwa Polskiego.

W kolejnej partii opracowania dokonano dla czytelnika zagranicznego naszkicowania zasadniczych postanowień Konstytucji z roku 1815 ze szczególnym uwzględnieniem tych regulacji, które odnoszą się do kwestii nadrzędności Konstytucji oraz prawa karnego.

Trzecia, właściwa cześć opracowania omawia zagadnienie nadrzędności Konstytucji 1815 rokuna przykładzie procesu legislacyjnego jedynej pełnej kodyfikacji całej gałęzi prawa (obok Kodexu Cywilnego Królestwa Polskiego z 1825 r., stanwiącego, jak wiadomo, w istocie drobną nowelizację Kodeksu Napoleona) jaka została przyjęta w Królestwie Polskim: Kodeksu Karzącego z roku 1818. Analiza stanowisk posłów i senatorów na Sejmie roku 1818 wprost potwierdziła, iż zarzut niekonstytucyjności tudzież argument o zgodności z Konstytucja był szeroko powoływany zarówno przez zwolenników jak i przez przeciwników projektu tej ustawy. Zgłoszone przez posłów poprawki dowodzą dążności posłów do możliwie dalekiego związania władzy sadowniczej normą prawnokarna w myśl rygorystycznie pojmowanej zasady nullum crimen sine lege certa i oświeceniowego ograniczania roli sędziego w sferze wykładni przepisów prawno-karnych.

Stad też skonstatować należy, iż zrodzona w Oświeceniu koncepcja hierarchicznej nadrzędności Konstytucji była już wtedy—przynajmniej wśród przedstawicieli polskiego Sejmu-rozpowszechniona. Uwidacznia to semantyka występująca w wypowiedziach posłów, którzy nierzadko odwołują się do „konstytucyjności” (zgodności z Konstytucją) proponowanego projektu, sematyka mająca przecież czytelną, późnooświeceniową prowenieniecję. Co więcej, analiza samego tekstu uchwalonego Kodeksu Karzącego dowodzi, iż stanowił on akt normatywny dostosowany do postanowień obowiązującej Konstytucji, a normy prawne, które mogłyby budzić wątpliwości jako sprzeczne z tym nadrzędnym aktem normatywnym występują absolutnie wyjątkowo. 


\section{References}

Askenazy S (1907) Rosja—Polska 1815-1830. Lwów, Warszawa

Askenazy S (1937) Szkice i Portrety. Warszawa

Bardach J, Leśnodorski B, Pietrzak M (1979) Historia Państwa i Prawa Polskiego, Warszawa

Bartoszewicz K (1916) Utworzenie Królestwa Kongresowego. Kraków

Barzykowski S (1883) Historia powstania listopadowego, vol I. Poznań

Borkowska-Bagieńska E (1986) „Zbiór Praw Sądowych” Andrzeja Zamoyskiego. Poznań

Brzeziński W (1830) Odpowiedź na artykuł pana Romualda Hubego w Themis Polskiej, tomie V, zeszyt 3, od K. 365 do 387 zamieszczony. Themis Polska, VII:97-108

Czartoryski A (1860) Żywot Juliana Niemcewicza. Poznań

Czartoryski A (1888) In: Adam Gielgud (ed) Memoirs of Prince Adam Czartoryski, vol II, London

Czubaty J (2011) Księstwo Warszawskie 1807-1815. Warszawa

Czyżak M (2012) Prawo Karne Wojskowe Okresu Królestwa Polskiego (1815-1831). Wojskowy Przegląd Prawniczy 3:1-11

D’Herbelot A (1830) Esquisses historiques-Le Royaume de Pologne depuis 1815. Extrait de la revue encyclopédique $1: 1-32$

Dembski K (1974) Polonia Restiuta-kontynuacja czy państwo nowe? Czasopismo Prawno-Historyczne (XXVI) 2:167-192

Deseure B (s.a.) National Sovereignty in the Belgian constitution of 1831. On the meaning(s) of Article 25. In: Müßig U (ed) Reconsidering constitutional formation I National Sovereignty. A comparative analysis of the juridification by constitution, s.l., s.n

Dziadzio A (2008) Powszechna Historia Prawa. Warszawa

Dzierożyński D (1830a) Uwagi nad prawem karnem polskiem. Cześć pierwsza Themis Polska, VIII: $1-25$

Dzierożyński D (1830b) Uwagi nad prawem karnem polskiem. Cześć druga. Themis Polska, VIII:369-391

Gąsiorowska N (1916) Wolność druku w Królestwie Kongresowym 1815-1830. Warszawa

Handelsman M (1914) Pod znakiem Napoleona. Próba wprowadzenia w Księstwie Warszawskim Kodeksu karnego Napoleona. Warszawa

Handelsman M (1915) Trzy Konstytucje (1791, 1807, 1815), Krakow, Warszawa-Lwów

Hoffmann KB (1831) Rzut oka na stan polityczny Królestwa Polskiego pod panowaniem rosyjskiem od 1815-1830, Warszawa

Hube R (1829) Art. 227 kodeksu karnego jak stosowany być powinien. Themis Polska V:365-387

Hube R (1863) Studia nad Kodeksem karnym 1818 r., vol. I. Warszawa

Iwaszkiewicz J (1912) Litwa w roku 1812, Kraków i Warszawa

Izdebski H (1972) Litewskie projekty konstytucyjne z lat 1811-1812 i ich wpływ na Konstytucję Królestwa Polskiego. Czasopismo Prawno-Historyczne (XXIV) 1:93-135

Izdebski H (1990) Ustawa Konstytucyjna Królestwa Polskiego z 1815 r. In: Kallas M (ed) Konstytucje Polski, vol. I. Warszawa

Kallas M (1969) Zapomniany projekt konstytucji polskiej z 1814 roku. Zeszyty Naukowe UMK, Prawo IX:103-116

Karamzin N (1818) Mémoires sur le rétablissement de la Pologne présente à l'empereur Alexandre le 17 Octobre 1819 (unpublished source avalable in Bibliothèque Polonaise à Paris, signature BPP 344, position 6)

Kowalski M (2013) Księstwa Rzeczypospolitej. Państwo Magnackie jako region polityczny, Warszawa, pp 255-256

Kozłowski WM (1907) Autonomia Królestwa Polskiego. Warszawa

Koźmian K (1858) Pamiętniki, Oddział I. Poznań

Kutrzeba S (1916) Sprawa polska w Królestwie Polskim 1815-1915. Lwów

Lelewel J (1961) Trzy Konstytucje polskie. Przedmowa do wydania francuskiego. In: Lelewel J (ed) Dzieła, vol VIII. Warsaw 
Mażewski L (2014) Księstwo Warszawskie i Królestwo Polskie z punktu widzenia prawa międzynarodowego. Panstwo i Prawo 2:62-71

Mecca G (s.a.) The omnipotence of parliament in the legitimisation process of 'representative government' under the albertine statute (1848-1861). In: Müßig U (ed) Reconsidering constitutional formation I National Sovereignty. A comparative analysis of the juridification by constitution, s.l., s.n

Mencel T (1968) Społeczeństwo w życiu politycznym królestwa polskiego. Przeglad Historyczny 4(LIX):629-659

Michalski J (1958) Studia nad reformą sądownictwa i prawa sądowego w XVIII w., part I. Wrocław-Warszawa

Mościcki HS (1924) Pod berłem carów. Warszawa

Müßig U (2014) Reconsidering constitutional formation - research challenges of comparative constitutional history. Giornale di Storia Costituzionale 18:229-254

Müßig U (2016) Aspects for ReConFort II decisive constitutional normativity (unpublished ReConFort discussion paper)

Müßig U (s.a.) Juridification by constitution. National Sovereignty in eighteenth and nineteenth century Europe. In: Müßig U (ed) Reconsidering constitutional formation I National Sovereignty. A comparative analysis of the juridification by constitution. s.l., s.n

Mycielski M (2010) Rząd Królestwa Polskiego wobec sejmików i zgromadzeń gminnych 18151830. Warszawa

Nawrot D (2008) Litwa i Napoleon w 1812 roku. Katowice

Niemojowski W (1818) Głosy posła kaliskiego, Poznań

Ogiński MK (1872) Pamiętniki o Polsce i o Polakach od r. 1788 aż do końca 1815 r. Poznań

Olechowski T (in print) Legal hierarchies in the works of Hans Kelsen and Adolf Julius Merkl. In: Müßig U (ed) Reconsidering constitutional formation I National Sovereignty. A comparative analysis of the precedence of constitution, s.l

Roztworowski M (1915) Prawna geneza Księstwa Warszawskiego i Królestwa Polskiego. Kraków

Skarbek F (1820) Słowo o wyborach. Orzeł Biały I:57-73

Skarbek F (1821) List drugi. Sybilla Nadwiślańska I(2):117-131

Skowronek J (1969) Antynapoleońskie koncepcje Czartoryskiego. Warszawa

Skowronek J (1995) Eksperyment liberalizmu parlamentarnego w Królestwie Polskim. Przegląd Humanistyczny 3: 5-13

Śliwowski J (1958) Kodeks karzący Królestwa Polskiego (1818 r.): historia jego powstania i próba krytycznej analizy (Annex). Warszawa

Smolka S (1907) Polityka Lubeckiego przed powstaniem listopadowym, vol II. Kraków

Stourzh G (2017) The development of constitutional precedence and the constitutionalization of individual rights. In: Müßig U (ed) Reconsidering constitutional formation I National Sovereignty. A comparative analysis of the precedence of constitution, s.l. (in print)

Szafrański W (2007) Kodeks Stanisława Augusta. Poznań

Szoper D (2004) Pod władzą carów: ziemie byłego Wielkiego Księstwa Litewskiego w XIX wieku. Czasy Nowożytne (16)

Szymaniec P (2014) Fryderyk Skarbek o konstytucji Królestwa Polskiego z 1815 roku i o statucie organicznym z roku 1832. Czasopismo Prawno-Historyczne 2

Tarnowska A (s.a.) The Sovereignty issue in the public discussion in the Era of the Polish 3rd May constitution (1788-1792). In: Müßig U (ed) Reconsidering constitutional formation I National Sovereignty. A comparative analysis of the juridification by constitution. s.l., s.n

Thaden EL (1984) Western Borderlands 1710-1870, Princeton 
van Eemeren FH (2010) Strategic manoeuvring in argumentative discourse. Amseterdam, Philadephia

Witkowski W (1988) Problem niezawisłości sądów a postawa Polskich prawników w Królestwie Kongresowym (Do 1876 r.). Palestra 7:35

Open Access This chapter is licensed under the terms of the Creative Commons Attribution 4.0 International License (http://creativecommons.org/licenses/by/4.0/), which permits use, sharing, adaptation, distribution and reproduction in any medium or format, as long as you give appropriate credit to the original author(s) and the source, provide a link to the Creative Commons license and indicate if changes were made.

The images or other third party material in this chapter are included in the chapter's Creative Commons license, unless indicated otherwise in a credit line to the material. If material is not included in the chapter's Creative Commons license and your intended use is not permitted by statutory regulation or exceeds the permitted use, you will need to obtain permission directly from the copyright holder.

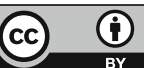

